\title{
Mucopolysaccharidoses and mucolipidoses
}

\author{
F. VAN HOOF
}

From the Laboratoire de Chimie Physiologique, Université Catholique de Louvain, and International Institute of Cellular and Molecular Pathology, Brussels, Belgium

Many different syndromes are classified as mucopolysaccharidoses, and, despite remarkable progress in the biochemical understanding of these diseases, much remains to be learned and many cases still escape classification.

Mucopolysaccharidoses are inborn storage diseases, characterized by a complex accumulation of mucopolysaccharides and of glycolipids within the lysosomes. Sixteen human diseases correspond to this definition, of which nine have been presently explained by the deficiency of an acid hydrolase. They are somewhat arbitrarily divided into mucopolysaccharidoses and mucolipidoses. In mucopolysaccharidoses, mucopolysaccharides are the main storage substances, although an abnormal accumulation of complex lipids is practically always disclosed at least by the ultrastructural examination. Excessive urinary elimination of mucopolysaccharides also characterize these diseases. In mucolipidoses, mucopolysacchariduria is usually normal and the accumulation of complex lipids is more prominent, or has been recognized before that of polysaccharides.

Except for Hunter disease all these pathological conditions are autosomal recessive disorders. The present paper summarizes the main features characterizing these storage diseases, and discusses their pathogenesis.

\section{Historical and Pathogenetic Considerations}

The evolution of knowledge concerning mucopolysaccharidoses and mucolipidoses, and the successive hypotheses formulated to explain their pathogenesis illustrate how scientific progress requires the united efforts of researchers in several disciplines.

First recognized as a bone dystrophy, around 1920, the 'Hunter-Hurler syndrome' long remained an entirely unexplained inherited disorder. Pathological studies have, however, indicated that cellular alterations are generalized and not restricted to bone. Histochemical analyses first classified the syndrome with the lipidoses (Tuthill, 1934), but later drew attention to the tissue accumulation of mucopolysaccharides (Brante, 1952).
THE CHEMICAL ERA

Chemical studies, performed mainly by groups working with A. Dorfman, in Chicago and $\mathrm{K}$. Meyer, in New York, have provided most of the new knowledge in the field by analysis of tissue and urinary mucopolysaccharides in patients (Dorfman and Lorincz, 1957; Meyer, Grumbach, Linker, and Hoffman, 1958; Meyer, Hoffman, Linker, Grumbach, and Sampson, 1959). These provided the basis for the subdivision of the 'Hurler syndrome' into six subgroups (McKusick, Kaplan, Wise, Hanley, Suddarth, Sevick, and Maumanee, 1965). The possibility that mucopolysaccharidoses could result from an excessive biosynthesis of mucopolysaccharides was suggested by Matalon and Dorfman (1966).

\section{THE LYSOSOMAL THEORY}

Meanwhile, in Louvain, lysosomes had been discovered by C. de Duve (de Duve, Pressman, Gianetto, Wattiaux, and Appelmans, 1955), their role in intracellular digestion established (for reviews, see de Duve and Wattiaux, 1966; Dingle and Fell, 1969), and the first example of a disease (type II glycogenosis) resulting from a deficiency of a lysosomal hydrolase recognized by $\mathbf{H}$. G. Hers $(1961,1963)$. This finding allowed Hers to formulate the general concept of 'inborn lysosomal diseases' (see also Hers, 1965, 1973; Hers and Van Hoof, 1969, 1970).

Inborn lysosomal diseases have the following characteristics. (1) They are inherited storage disorders with symptoms developing progressively. (2) The stored material accumulates within lysosomes; this can be demonstrated by ultrastructural studies. (3) The stored material is, as a rule, heterogeneous. Indeed, most lysosomal enzymes have little specificity concerning the lipid, polysaccharide, or glycoprotein nature of their substrate, and are only specific of one type of chemical linkage. Deficiency of $\alpha$-fucosidase, for instance, results in the simultaneous accumulation of polysaccharide fragments, of oligosaccharides originating from glycoproteins and of oligoglycosyl-ceramides, all of them containing fucose in the $\alpha$-configuration. 
(4) One of the lysosomal hydrolases is missing. (5) Material accumulating in patient's cells must be digestible by the enzymes present in normal lysosomes.

Hers suggested that this concept was not restricted to type II glycogenosis but applied to most of the known storage diseases, such as the lipidoses and mucopolysaccharidoses and in 1963, research was initiated, in Louvain, into the electron microscopic examination and systematic assay of lysosomal enzyme activity in tissues from patients with mucopolysaccharidoses.

\section{THE ULTRASTRUCTURAL EVIDENCE}

Ultrastructural studies disclosed, in the liver of patients with the Hurler syndrome, the enlargement of lysosomes that was predicted by the concept of 'inborn lysosomal diseases' (Van Hoof and Hers, 1964). Large clear vacuoles, limited by single membranes, were found in the cytoplasm of the cells, while secondary lysosomes of normal appearance ('dense bodies') had practically disappeared (fig 1).

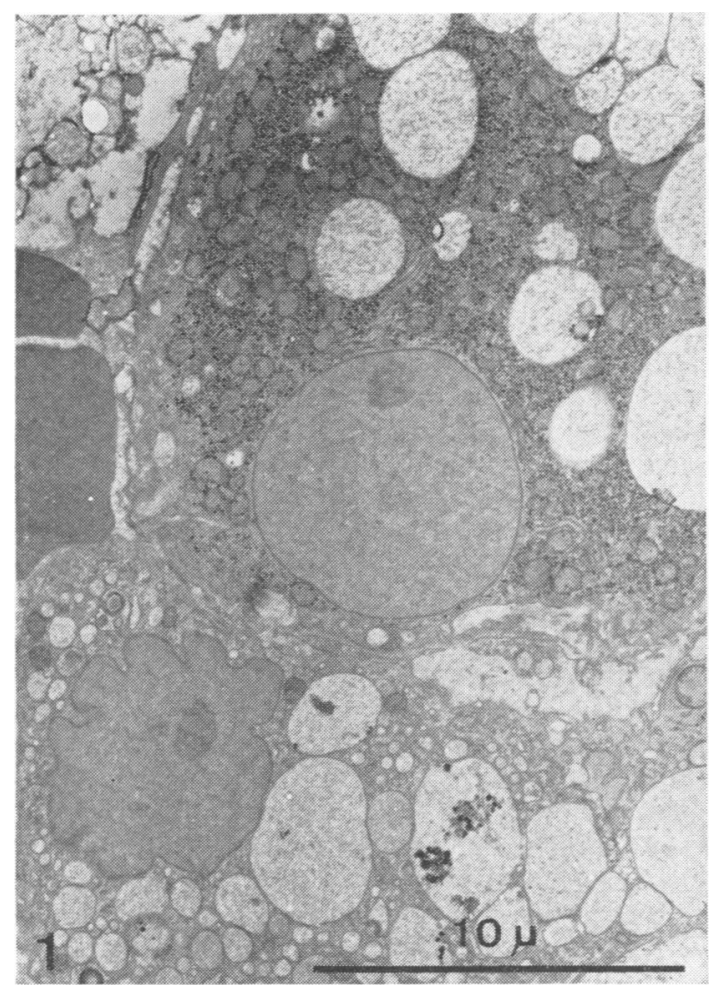

Fig 1 Liver ultrastructure in Hunter disease. Both the hepatocyte (above) and the Kupffer cell (below) contain clear vacuoles, which are lysosomes overloaded with mucopolysaccharides (from Van Hoof and Hers, 1964).
The presence of mucopolysaccharides within lysosomes did not provide the proof that mucopolysaccharidoses result from the absence of lysosomal enzymes. As pointed out by the authors, excessive synthesis of normal macromolecules, such as mucopolysaccharides, could account for the overloading of lysosomes, if the latter took up these molecules faster than they degraded them. An example of that situation had been provided by injecting laboratory animals with dextran, a polyglucoside slowly digestible by the lysosomes (Daems, 1962; Wattiaux, 1966). Also, although unlikely, it was possible that the mucopolysaccharide accumulated because its structure was abnormal, for example, that it contained one or more chemical bonds resistant to normal lysosomal hydrolases. Chemical analyses have not disclosed such structural abnormalities in the mucopolysaccharidoses.

Besides their role in understanding the pathogenesis of mucopolysaccharidoses, ultrastructural investigations are helpful in the recognition of new syndromes and in prenatal diagnosis.

\section{THE ENZYMATIC EVIDENCE}

In parallel with ultrastructural studies, the activity of lysosomal hydrolases was measured in tissues from patients in the hope of finding the missing enzyme. Little interest was paid to proteolytic enzymes. Indeed, a dysfunction of lysosomal proteolysis would first result in peptide accumulation and perhaps in the storage of proteoglycans. In fact, it had been demonstrated that the substances accumulated in tissues or excreted in urine in cases of mucopolysaccharidosis are not the original proteoglycans, but partially degraded products with very little protein residue.

Our attention was thus focused on the glycosidases, and among them, mainly on $\mathrm{N}$-acetyl- $\beta$ hexosaminidase and $\beta$-glucuronidase, whose absence was most likely to explain the accumulation of glycosaminoglycans. Surprisingly, the first enzyme determinations demonstrated hyperactivity of these two enzymes. Several other glycosidases were also hyperactive, but acid $\beta$-galactosidase was partially deficient. The significance of the latter enzyme abnormality was not clear, since the lesion was demonstrated not only in Hurler but also in Hunter and in Sanfilippo patients (Van Hoof and Hers, 1967a).

However, when more enzymes were assayed in tissues from other patients, deficiency of lysosomal hydrolases were discovered, such as the lack of acid $\beta$-galactosidase, responsible for $\mathrm{GM}_{1}$-gangliosidosis (Sacrez, Juif, Gigonnet, and Gruner, 1967), $\alpha$-mannosidase deficiency in mannosidosis (Öckermann, 1967) and the defect of $\alpha$-fucosidase 
in fucosidosis (Van Hoof and Hers, 1968a, b). Thus, at least these three diseases, closely related to the Hurler syndrome, were rightly considered as 'inborn lysosomal diseases'.

At the present time, most of the mucopolysaccharidoses and mucolipidoses have been explained by the deficiency of an acid hydrolase, belonging probably or certainly to the lysosomes, and it is not very hazardous to predict that the few diseases which still remain to be elucidated will soon be explained by a similar enzyme defect. Keratansulphate accumulating in Morquio disease, for instance, could conceivably result from the lack of a sulphatase acting on galactose sulphate.

\section{STUDIES ON CULTURED FIBROBLASTS}

Considerable progress in the study of mucopolysaccharidoses and mucolipidoses resulted, finally, from the study of cultured fibroblasts, mostly by E. F. Neufeld and her coworkers, in Bethesda, who have demonstrated that the accumulation of mucopolysaccarides results from a disturbance in catabolism and not from their overproduction (Frantantoni, Hall, and Neufeld, 1968a). The discovery of the presence in the culture medium of specific 'corrective factors' able to restore the normal catabolism of mucopolysaccharides in fibroblasts from patients (Fratantoni, Hall, and Neufeld, $1968 \mathrm{~b}$ ) has been of even greater importance.

The study of these 'corrective factors' in many cell cultures resulted in the demonstration of the heterogeneity of the Sanfilippo syndrome and the recognition that the Hurler and Scheie syndromes are allelic disorders (see below). Analysis of the corrective factors revealed that they are acid hydrolases, all probably belonging to the lysosomal apparatus.

\section{Hurler Disease}

Mucopolysaccharidosis type I bears the name of Gertrud Hurler, who gave, in 1919, its first detailed description. Hurler disease should not be confused with the 'Hurler syndrome' used for years to designate all forms of mucopolysaccharidosis. One of the mucolipidoses was also originally named with reference to it, GM1-gangliosidosis, which was defined among cases reported as suffering from a 'pseudo-Hurler syndrome'.

\section{CLINICAL FEATURES}

Although the 'Hurler syndrome' is characteristic and easily recognized (for reviews see McKusick et al, 1965; Leroy and Crocker, 1966; Loeb, Cremer, and Denolin-Reubens, 1969a; Dorfman and Matalon, 1972; Spranger, 1972a), a few clinical signs

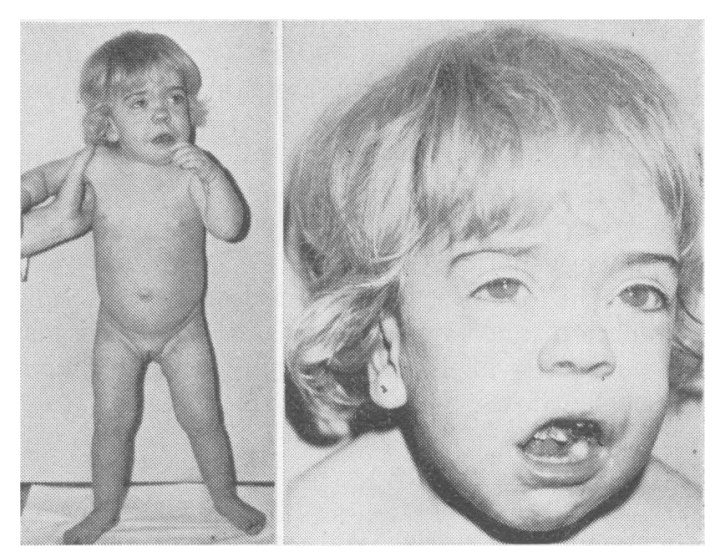

Fig 2 Clinical appearance of a $2 y r-2$ mth-old girl with Hurler disease. Note incipient umbilical hernia and facial dysmorphism, with hypertelorism, depression of the bridge of the nose, anteverted nostrils, prominent forehead, and somewhat thick lips; dentition is irregular and hair is coarse.

distinguish type I mucopolysaccharidosis more precisely.

At birth patients appear normal, and the first symptoms are noticed only after a few weeks or months. The disease is progressive and leads to the death before puberty. Short stature is frequent in these children, who display a series of malformations. Typical facial deformities (fig 2) led Ellis, Sheldon, and Capon in 1936 to give the name 'gargoylism' to the syndrome. Corneal opacities, sometimes discrete, are an important sign in distinguishing between the different mucopolysaccharidoses. Teeth are widely and irregularly spaced and the gums are hypertrophic. Patients suffer from chronic nasal discharge. The neck is often short, the thorax broad, and the abdomen protuberant as a result of combined vertebral deformities and visceromegaly. Most of these children suffer from herniae (umbilical and inguinal). Long bones are shortened and thickened. Joint mobility is limited. Skin is thick and hair is coarse. Multiple heart lesions can be detected, involving myocardium, pericardium, endocardium, and, most frequently, heart valves. Heart failure is a frequent cause of death. Neurological disturbances are reflected in progressive psychomotor retardation. Increased susceptibility to infections often occurs in this, as in the other forms of mucopolysaccharidosis and mucolipidosis.

\section{BIOLOGICAL DATA}

Radiography discloses generalized disturbances in bone growth with typical wedge-shaped vertebrae. Haematological studies reveal vacuolated cells in 
bone marrow and circulating leucocytes. As first demonstrated by Dorfman and Lorincz (1957), urine contains an excess of mucopolysaccharides. Chromatography, electrophoresis, or hydrolysis by specific enzymes indicates that the excreted polysaccharide is a mixture of dermatan sulphate and heparan sulphate.

\section{MOR P HOLOGY}

In this generalized disease, light microscopy displays vacuolization or ballooning of most cells. The accumulated material in brain neurones has the staining properties of complex lipids, as first pointed out by Tuthill (1934) at the necropsy on one of Gertrud Hurler's original patients, whereas, in fibroblasts, chondrocytes, and visceral parenchymal cells the content of the vacuoles is water-soluble and metachromatic, due to the presence of acid mucopolysaccharides, as first demonstrated by Brante (1952). However, these vacuoles also frequently contain material staining as lipid (see, for instance, Wolfe, Blennerhasset, Young and Cohen, 1964).

Electron microscopy confirms the heterogeneity of deposits, mucopolysaccharide material being electron-lucid, and complex lipids usually appearing as electron-dense lamellar deposits. But the most important contribution of ultrastructural studies in the mucopolysaccharidoses has been the demonstration of the lysosomal nature of the vacuoles (see above). In liver cells, lysosomes distended by polysaccharide material appear as clear vacuoles limited by a unit membrane. Vacuoles are frequently larger than the cell nucleus, and the dense bodies, with the normal appearance of secondary lysosomes, have disappeared (figs 3,4 ). The presence of acid phosphatase in these vacuoles was first demonstrated by Wallace, Volk, Schneck, and Kaplan (1966). In brain neurones, lysosomes are loaded with osmiophilic material disposed in parallel lamellae more or less perpendicular to the membrane

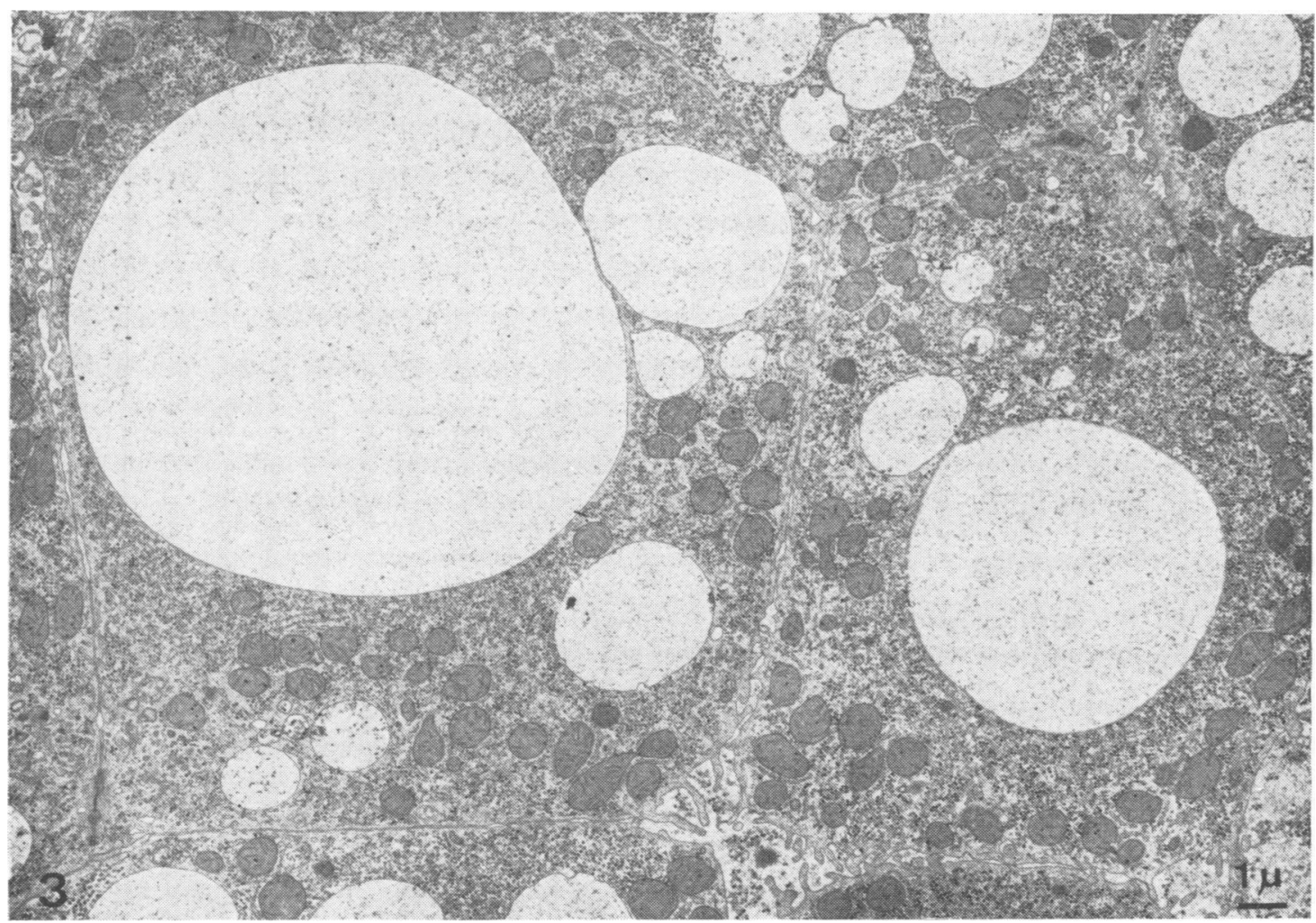

Fig 3 Hepatocytes in Hurler disease. Clear vacuoles, limited by a single membrane and containing finely flocculent material, occupy an important part of the cytoplasm. There are no peribiliary dense bodies. The other cell constituents are normal. 


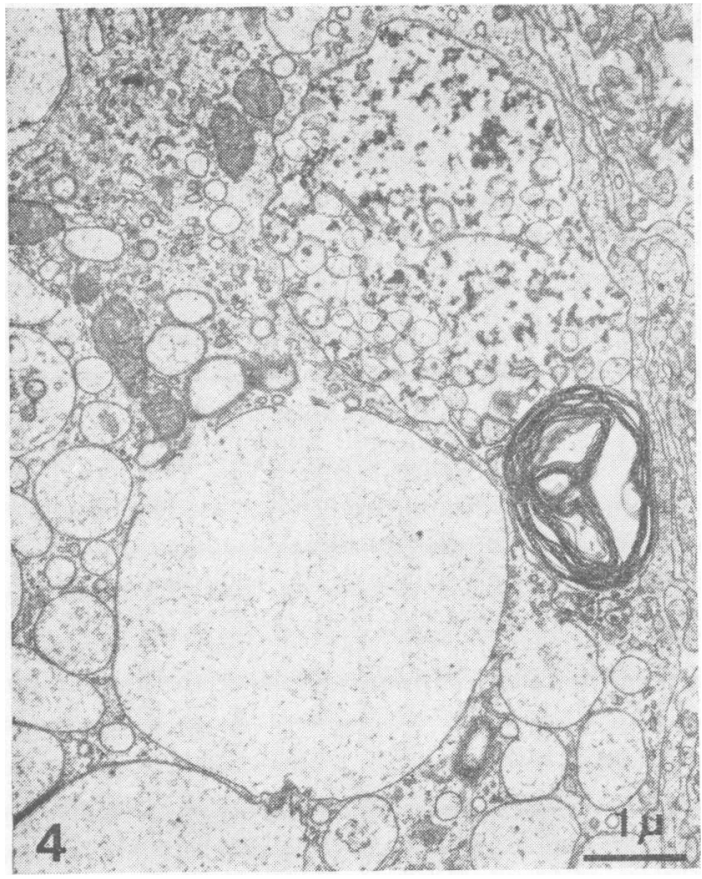

Fig 4 Kupffer cell, in the same patient. The heterogeneity of the vacuolar content is obvious. Pseudomyelin figures indicate the presence of complex lipids.

Fig 5 Abdominal muscle in Hurler disease. Subsarcolemmal lysosome containing both lamellarand finely granular material, indicating a moderate but definite accumulation of glycolipids and polysaccharides in muscle tissue.

limiting the organelles. Because of this typical appearance, these lipid inclusions have been called 'zebra bodies' (Aleu, Terry, and Zellweger, 1965). Intermediate types of vacuole, containing both lipid lamellae and clear material (fig 5), are encountered in many tissues. In the cytoplasm of intestinal absorptive cells enlarged lysosomes with a finely flocculent matrix have been observed by Daems, van Gemund, Vio, Willighagen, and Den Tandt (1973) and by Ginsel, Daems, Emeis, Vio, and van Gemund (1973). Ultrastructural investigations have disclosed lysosomal overloading in practically all types of cells demonstrating that Hurler disease is a generalized disorder.

Electron micrographs from liver tissue have been submitted to quantitative morphometric analysis (Van Hoof, 1972, 1973a), from which it was calculated that the lysosomal volume is 30 - to 77 -fold larger in patients than in controls. Lysosomes occupy in most patients over $20 \%$ of the cell volume. This is surprisingly large, compared with the relatively modest amount of mucopolysaccharide revealed by

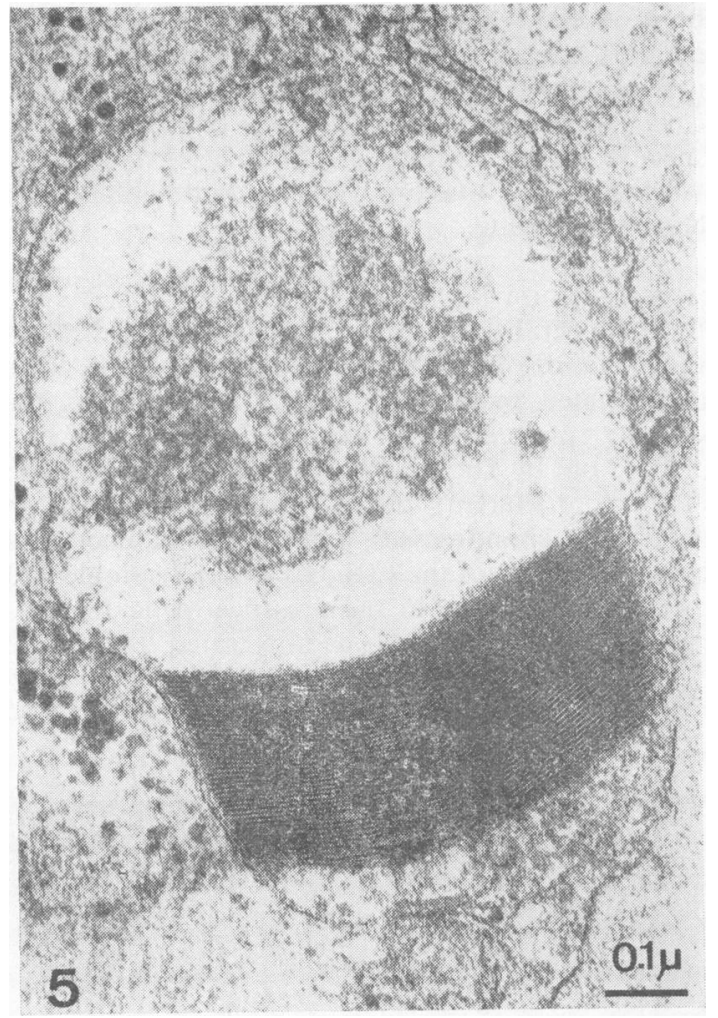

chemical analyses $(0 \cdot 5-2 \%$ of the wet weight of liver).

\section{CHEMISTRY}

The mucopolysaccharides which accumulate in tissues are the same as those present in excess in urine. This material is, however, different from the native proteoglycans. Glycosaminoglycans are partially depolymerized and practically all the peptidic moiety of the original molecules has been lost. Mucopolysaccharides, mostly dermatan sulphate and heparan sulphate represent $0 \cdot 5-2 \%$ of the weight of liver tissue, and about half that amount in spleen; glycosaminoglycan accumulation in brain is much less important. Urine may contain over $100 \mathrm{mg}$ uronic acid per day, which corresponds to more than $200 \mathrm{mg}$ acid mucopolysaccharide or 10-20 times the physiological mucopolysacchariduria. This amount should be compared with the $250 \mathrm{mg}$ of mucopolysaccharide that Leaback (1970) has calculated as the normal daily turnover of these substances in man.

The lipid part of the deposit is quite variable and has been less extensively studied. Most frequently reported are a slight elevation ( 1.5 to 5 times normal) of lactosylceramide and of the simplest gangliosides $\left(\mathrm{GM}_{1}\right.$ to $\left.\mathrm{GM}_{3}\right)$ in the central nervous system (Ledeen, 
1966; Borri, Hooghwinkel, and Edgar, 1966; Philippart, 1966; Clausen, Dyggve, Melchior, and Christensen Lou, 1967; Taketomi and Yamakawa, 1967; Suzuki, 1967; Wherrett, 1968; Kint, Dacremont, Carton, Hooft, and Loeb, 1971).

\section{ENZYMOLOGY}

The causal lesion of Hurler disease is a complete lack or a profound deficiency of $\alpha$-L-iduronidase. This was first suggested by Matalon, Cifonelli, and Dorfman (1971), who observed that the release of iduronate from desulphated heparan sulphate was deficient when patient's fibroblasts were used as the source of enzyme. An artificial substrate was then synthesized by Weissmann and Santiago (1972), who demonstrated that $\alpha$-L-iduronidase is a lysosomal enzyme, at least in rat liver. With this substrate, the lack of iduronidase was unequivocally demonstrated in liver, cultured fibroblasts, and urine from Hurler patients (Bach, Friedman, Weissmann, and Neufeld, 1972; Matalon and Dorfman, 1972). The same lesion was found, by these authors, in the Scheie syndrome (mucopolysaccharidosis type $\mathrm{V}$ ), indicating that types $\mathrm{I}$ and $\mathrm{V}$ are allelic disorders. The correspondance between $\alpha$-L-iduronidase and the 'Hurler corrective factor', which had already been discovered by Fratantoni et al (1968b) in cultured fibroblasts, was demonstrated by Bach et al (1972). The lack of lysosomal $\alpha$-L-iduronidase adequately explains the accumulation within the lysosomes of Hurler patients of partially degraded dermatan sulphate and heparan sulphate, since both these mucopolysaccharides contain iduronic acid.

Many other lysosomal hydrolases are abnormally active in Hurler tissues, but these disturbances must not be considered primary (Van Hoof and Hers, 1967a, 1968a; Van Hoof, 1973a). This most probably reflects reactions of the lysosomal system to the condition created by the lack of $\alpha$-iduronidase. Liver acid $\beta$-galactosidase is poorly active (one sixth of the mean value of controls), but never completely absent. Brain, muscle, skin, and some other tissues also display this deficiency, while other cells, like leucocytes or cultured fibroblasts, do not. Different isoenzymes of $\beta$-galactosidase have been detected in man. The deficient fractions in Hurler disease are the most thermolabile components, optimally active at pH 3.6, and corresponding to the two slow moving bands in electrophoresis (Ho and O'Brien, 1969). Accordingly, $\alpha$-L-arabinosidase is also deficient: enzymatic hydrolysis of $\alpha$-L-arabinosides and of $\beta$-D-galactosides is due to the same proteins. Activity of acid $\alpha$-galactosidase is also sometimes reduced. Although considered secondary effects, the low activity of these two acid galactosidases might explain the accumulation of glycolipids within the lysosomes. On the other hand, many glycosidases, as well as some other lysosomal hydrolases, are hyperactive. This increase in activity, which may be more than 10 -fold in liver, concerns mainly $\beta$-glucuronidase and $\beta$-hexosaminidase. There are reasons to believe that mucopolysaccharides present in the lysosomes of the patients act as stabilizers for acid glycosidases, slowing down their natural degradation (Van Hoof and Hers, 1972). Kint, Dacremont, Carton, Orye, and Hooft (1973) have demonstrated that these enzymes form associated complexes with mucopolysaccharides. It must be noted that hyperactivity of acid hydrolases has been found in most of the experimental conditions in which lysosomes become overloaded.

PRENATAL DIAGNOSIS AND HETEROZYGOTE DETECTION

Attempts at prenatal diagnosis were based on two different techniques. The first method uses cultured amniotic cells, in which synthesis and accumulation of mucopolysaccharides can be calculated from the rate of radioactive sulphate incorporation into intracellular macromolecular material (Fratantoni et al, 1969). Typing of the disease can be achieved by using the specific corrective factors, or by adding partially purified $\alpha$-L-iduronidase to the culture medium (Bach et al, 1972). This time-consuming method gives reliable results. Matalon, Dorfman, Nadler, and Jacobson (1970) proposed a more direct technique which consists in measuring the amount of mucopolysaccharides present in the amniotic fluid. These authors (1972) recognize, however, that it has led to falsely negative results in Hurler as well as in Sanfilippo disease, because of the large variation in mucopolysaccharide content of amniotic fluid, in both normal and pathological conditions.

Heterozygote detection is still practically impossible.

THERAPEUTIC ATTEMPTS

The observations by Di Ferrante, Nichols, Donnelly, Neri, Hrgovcic, and Berglund (1971) and by Knudson, Di Ferrante, and Curtis (1971) that plasma or leucocyte infusion was beneficial for Hurler patients has been followed by a large number of therapeutic attempts in different countries. The most impressive result of this therapy, according to these authors, was the appearance in urine of low-molecular-weight products of degradation of the mucopolysaccharides, which suggested that corrective factors were present in the transfused material and could act on the intralysosomal mucopolysaccharide deposits. In Louvain, the experience with both methods of therapy has not been very encouraging. Three patients received either plasma or leucocyte infusion and one of these 
attempts was followed closely. No significant rise in the urinary excretion of mucopolysaccharide fragments could be found and liver ultrastructure remained unchanged; the only encouraging feature was the less objective report that the parents estimated that there was some improvement in the behaviour of their child in the days following therapy (personal communication of $\mathbf{L}$. Corbeel, Department of Pediatrics, University Hospital). Other authors have also reported negative results (Crocker, 1972; Danes, Degnan, Salk, and Flynn, 1972; Dekaban, Holden, and Constantopoulos, 1972; Erickson, Sandman, Robertson, and Epstein, 1972; Spranger, 1972b; Booth and Nadler, 1973).

The purification of the missing enzyme will, in the future, provide a much more potent and specific agent in substitution therapy. Organ transplantation should also be considered, at least in the more slowly progressive patients, for this therapeutic approach has proved successful in Fabry disease, another inborn lysosomal storage disorder (for a review, see Desnick, Bernlohr, and Krivit, 1973).

\section{Hunter Disease}

Mucopolysaccharidosis type II was named after Charles Hunter who reported, in 1917, clinical observations on two brothers suffering from important chondroosteodystrophy. The disease is $\mathrm{X}$ linked recessive, as first demonstrated by $\mathrm{Njå} \mathrm{(1946).}$

CLINICAL FEATURES AND LABORATORY DATA These differ from those in Hurler disease by the absence of corneal clouding, and by the presence of peculiar smooth surfaced, normal coloured pin-head elevations of the skin. Hirsutism seems also more frequent and extensive than in the other types. Mental retardation is often moderate and survival to an adult age is not exceptional. Bone malformations, vacuolated leucocytes, and mucopolysaccaride excretion are similar in both Hurler and Hunter diseases, as are light and electron microscopic findings.

Chemical analysis indicates that the same products accumulate or are excreted in Hunter and Hurler diseases. Urine is somewhat richer in $\mathrm{N}$-sulphated hexosamine (Maroteaux, 1970). In one case a 13fold excess of digalactosyl ceramide and a two-fold excess of digalactosylglucosyl ceramide were noted in kidney (Kint et al, 1971).

\section{ENZYMOLOGY}

Hunter disease results from a deficiency of sulphoiduronate sulphatase (Bach, Eisenberg, Cantz, and Neufeld, 1973; Sjöberg, Fransson, Matalon, and Dorfman, 1973). The presence of sulphated iduronic

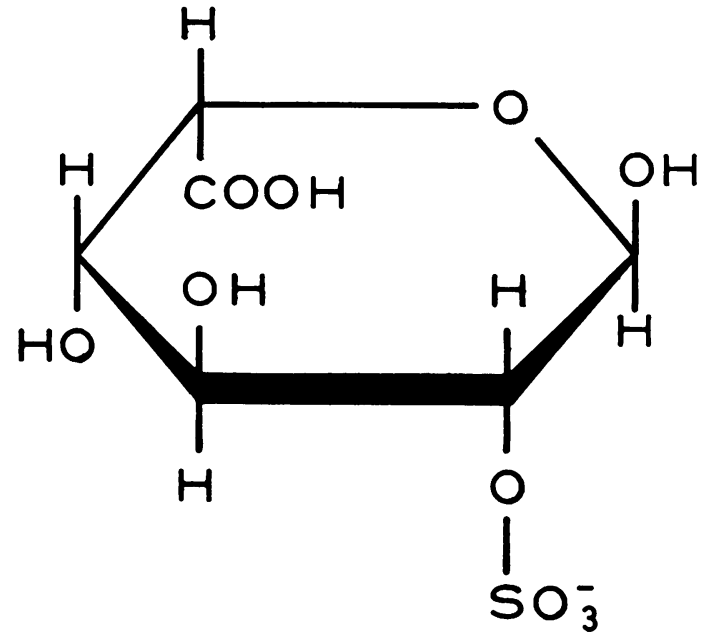

Fig 6 a-L-Sulphoiduronic acid. According to Seno et al (1972) the sulphate group might also be attached to carbon 3.

acid (fig 6) has been reported in dermatan sulphate (Malmström and Franson, 1971) and in heparin (Lindahl and Axelsson, 1971); the latter has a chemical structure similar to that of heparan sulphate. The Hunter corrective factor has been identified by Bach et al (1973) as sulphoiduronate sulphatase; this hydrolase, optimally active at $\mathrm{pH}$ $4 \cdot 0$, probably belongs to the lysosomes. Its absence accounts for the accumulation of partially degraded dermatan sulphate and heparan sulphate. Sjöberg et al (1973) have indeed demonstrated that sulphated iduronic acid is the terminal osidic group of dermatan sulphate fragments isolated from Hunter fibroblasts, while normal dermatan sulphate terminates with $\mathrm{N}$-acetyl-galactosamine sulphate.

No sulphoiduronic residues have been detected either in physiologically occurring glycolipids, nor in those present in excess in the brain of patients. As in Hurler disease, it is possible that the accumulation of glycolipids results from the secondary deficiency of $\beta$ - and sometimes $\alpha$-galactosidase. Hyperactivity of many other lysosomal hydrolases is also found in tissues from Hunter patients.

PRENATAL DIAGNOSIS AND THERAPEUTIC ATTEMPTS

These have been performed as in Hurler disease. The presence in urine from a Hunter patient of disulphated disaccharides containing iduronic acid was reported by Coppa, Singh, Nichols, and Di Ferrante (1973). According to these authors, intravenous infusion of a plasma fraction caused the disappearance of this disaccharide excretion. 


\section{Sanfilippo Syndrome}

Sanfilippo, Podosin, Langer, and Good, recognized in 1963 a Hurler-like syndrome characterized by the urinary excretion of an excess of heparan sulphate. Subsequent research on the specific corrective factors in fibroblast culture has indicated the existence of two distinct Sanfilippo diseases, subgroups A and B (Kresse, Wiesmann, Cantz, Hall, and Neufeld, 1971), in both of which the biochemical lesion is known. Except for the enzymatic deficiency, no significant differences allow these subgroups to be distinguished.

CLINICAL FEATURES AND LABORATORY DATA These allow of a relatively easy distinction from Hurler or Hunter disease. Many patients develop normally for two or three years before the first symptoms appear. Mental disturbances generally precede alterations of bone and cartilage. Hyperactivity, aggression, and later dementia contrasts with the apathy, low mental performance, but usually well preserved affective life, associated with mucopolysaccharidosis type I. Corneal opacities are rare and discrete. Death occurs in childhood. Morphological alterations are almost the same as in Hurler or Hunter diseases.

Chemical analysis indicates that heparan sulphate is the only, or at least, the predominant mucopolysaccharide accumulated and excreted. This polysaccharide, although its chemical structure is closely related to heparin, has only negligible effects on blood coagulation. No disease resulting from the accumulation of heparin has ever been reported.

\section{ENZYMOLOGY}

Sanfilippo A disease is due to a profound deficiency of a specific sulphatase, which acts on the Nsulphate groups present in heparin and heparan sulphate (Kresse and Neufeld, 1972; Kresse, 1973). Identity of the enzyme with Sanfilippo A corrective factor was demonstrated by these authors. This hydrolase is optimally active at $\mathrm{pH} 4 \cdot 0$, but its lysosomal nature has not yet been established. $\mathrm{N}$ - sulphatase deficiency can be demonstrated in peripheral leucocytes (Kresse, 1973).

In Sanfilippo B disease, $\mathrm{N}$-acetyl-a-glucosaminidase is virtually absent from all the tissues tested: fibroblasts, liver, kidney (O'Brien, 1972; von Figura and Kresse, 1972). We were recently able to show that the enzymatic defect can also be demonstrated in blood plasma (table I). The identity of the Sanfilippo B factor with $\mathrm{N}$-acetyl- $a$-glucosaminidase has been elegantly established by von Figura and Kresse (1972). The lysosomal nature of this enzyme had been proved in pig liver (Weissmann et al, 1967) and beef liver (Weissmann and Hinrichsen, 1969).

As already discussed in the case of Hurler and Hunter diseases, the enzymatic defect responsible for Sanfilippo A disease does not account for the deposition of complex lipids. This is less evident for the $\mathrm{N}$-acetyl- $\alpha$-glucosaminidase defect, for many glycolipids contain $\mathrm{N}$-acetylglucosamine of which the $\alpha$ or $\beta$-configuration has not always been clearly ascertained. As in Hurler and Hunter disease, liver acid $\beta$-galactosidase activity is frequently lower than one fifth of the mean control value, but normal activity is found in one out of three patients with the Sanfilippo syndrome. Hyperactive lysosomal hydrolases are the same as in the first two types of mucopolysaccharidosis.

PRENATAL DIAGNOSIS, HETEROZYGOTE DETECTION, AND THERAPEUTIC ATTEMPTS These have been performed as in mucopolysaccharidosis type I and II, and treatment by plasma or leucocyte transfusions has been attempted (Dean, Muir, and Benson, 1973). Heterozygote detection is feasible in type $B$ patients by measuring $\alpha$-glucosaminidase activity in cultured fibroblasts (O'Brien, 1972).

\section{Morquio Syndrome}

Mucopolysaccharidosis type IV was named after Morquio, who in 1929 gave the first description of the disease. Clinical heterogeneity is pronounced in this syndrome and it has been argued that type IV is

\begin{tabular}{lccc}
\hline & $N$-Acetyl-a-glucosaminidase & $N$-acetyl- $\beta$-glucosaminidase & $\beta$-Galactosidase \\
\hline Controls & 411 & 19640 & 405 \\
SD & 110 & 5000 & $(26)$ \\
(number) & $(12)$ & 114500 & $(14)$ \\
Patient D.S. & 7 & 26900 & 650 \\
Patient D.I. & 2 & 21400 & 350 \\
Patient D.JL & 9 & 11200 & 302 \\
Mother D. & 195 & 264 \\
\hline
\end{tabular}

Table I Acid hydrolase activity (pmol/min/ml) in plasma from controls and Sanfilippo B homozygotes and a heterozygote 
not a unified syndrome (Spranger, 1972a; Maroteaux, 1973).

Clinical features are dominated by the very pronounced bone deformities appearing usually between 1 and 2 years of age. Patients, who frequently survive to be adults, are severely dwarfed, with short neck and trunk, important vertebral lesions, and knock knees. Facial dysmorphism is characterized by prognathism. Deafness is frequent but mental retardation and corneal opacities are rare. Hepatomegaly is less pronounced than in Hurler disease.

LABORATORY AND ULTRASTRUCTURE DATA Circulating leucocytes contain metachromatic granules. Keratan sulphate is the major mucopolysaccharide excreted in urine. Liver Kupffer cells and dermal fibroblasts contain clear vacuoles, similar to those described in the first three types of mucopolysaccharidoses. In hepatocytes, however, most of the dense bodies have a normal appearance (Panizon, Sartorelli, and Perona, 1968; Tondeur and Loeb, 1969). Chondrocytes in epiphyseal plates are distended by numerous clear vacuoles (Maynard, Cooper, and Ponseti, 1973). Ultrastructural studies of other tissues have not, to our knowledge, been reported.

Mucopolysacchariduria is less than in Hurler disease. Keratan sulphate in urine is reported to be between two to three times (Linker, Evans, and Langer, 1970) and 400 times the normal value (Kaplan, McKusick, Trebach, and Lazarus, 1968). Lipid analysis of brain tissue has not, to our knowledge, been performed.

\section{ENZYMOLOGY}

The enzymatic defect responsible for the Morquio syndrome has not yet been discovered. The activity of the liver acid hydrolases is much less abnormal than in types I-III; $\beta$-glucuronidase and $\mathrm{N}$-acetyl- $\beta$ hexosaminidase are frequently hyperactive (Van Hoof, 1972, 1973a). It is remarkable that no deficiency of acid $\beta$-galactosidase has been found in this disease which is characterized by the elimination of the only mucopolysaccharide to contain galactose.

\section{Scheie Syndrome}

Mucopolysaccharidosis type $\mathrm{V}$ and Hurler disease are most probably allelic diseases (McKusick et al, 1972). The syndrome, correctly described by Scheie, Hambrick, and Barness, in 1962, as a 'forme fruste of Hurler's disease' is characterized by clinical manifestations similar to those of mucopolysaccharidosis type I, except for the absence of mental retardation, and the delayed appearance of the symptoms. The disease is frequently recognized only when patients enter school or even later, and many of them have an almost normal adult life, complaining only of joint stiffness, progressive corneal opacity, and tendency to herniae; some develop heart valve alterations and hearing defect (Dorfman and Matalon, 1972; Spranger, 1972a). As in Hurler disease, mucopolysacchariduria involves both dermatan sulphate and heparan sulphate.

Wiesmann and Neufeld demonstrated in 1970 that no cross correction was possible between Hurler and Scheie fibroblasts, and concluded that both syndromes are probably due to the same enzyme deficiency. This was confirmed by Bach et al (1972), who found no $\alpha$-L-iduronidase in Scheie fibroblasts.

\section{Maroteaux-Lamy Disease}

Mucopolysaccharidosis type VI was recognized in 1963 by Maroteaux, Lévêque, Marie, and Lamy, and named polydystrophic dwarfism by Maroteaux and Lamy (1965).

\section{CLINICAL FEATURES}

These are somewhat reminiscent of the Morquio syndrome in the importance of the skeletal lesions and the limitation of growth. Mental retardation is absent, but visceromegaly and corneal clouding exist as in Hurler disease. Spranger, Koch, McKusick, Natzschka, Wiedemann, and Zellweger (1970), and Spranger (1972a) distinguish a slowly evolving form, where death usually is due to heart failure, from a rapidly evolving form, in which skeletal and corneal lesions are extreme. Urine contains an excess of dermatan sulphate; heparan sulphate excretion is normal (Maroteaux et al, 1963).

The ultrastructure differs from that in Hurler disease by the much more moderate storage of electron-lucid material in lysosomes of hepatocytes (figs 7-8), while liver fibroblasts and Kupffer cells are at least as heavily loaded with mucopolysaccharides as in mucopolysaccharidosis type I (fig 7). Ocular tissues also contain numerous clear cytoplasmic vacuoles (Kenyon, Topping, Green, and Maumenee, 1972).

In accord with the ultrastructural appearances, chemical analysis of liver tissue reveals a smaller amount of stored mucopolysaccaride than in mucopolysaccharidosis types I-III: in the latter diseases mucopolysaccarides are about 25-75 times normal, while, in Maroteaux-Lamy disease, a 13-fold increase has been measured (Van Hoof, 1972).

\section{ENZYMOLOGY}

The missing enzyme responsible for the disease remains unknown, although the specific corrective, 


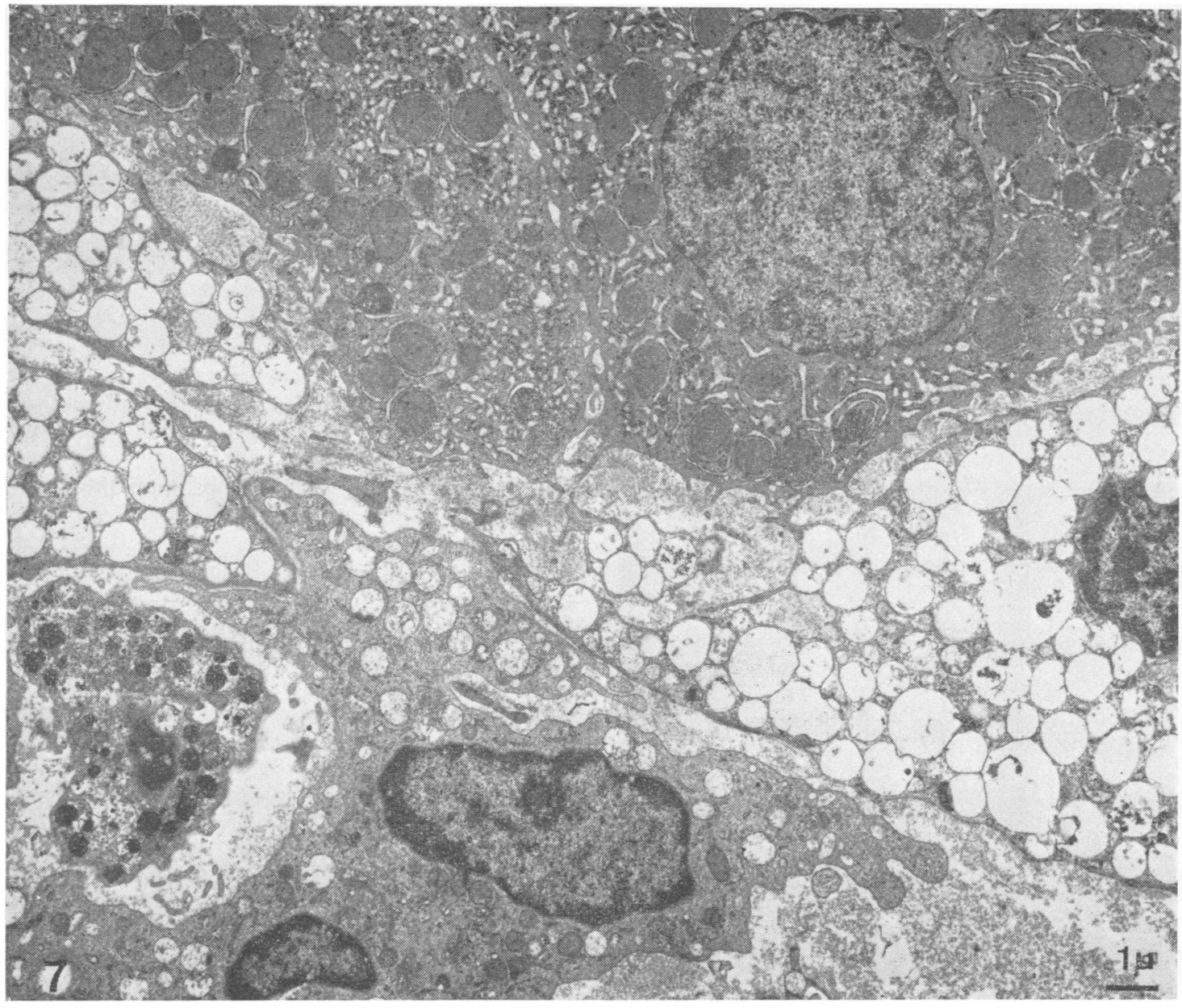

Fig 7 Liver ultrastructure in Maroteaux-Lamy disease. The parenchymal cells in the upper part of the micrograph have a normal appearance. In contrast, the fibroblasts and Kupffer cells are dilated by the accumulation of small clear cytoplasmic vacuoles. In the sinusoid, there is part of a macrophage in which the lysosomes contain mostly osmiophilic (dark) material.

factor is presently under study (Barton and Neufeld, 1972). The activity pattern of the liver acid hydrolases resembles that in Sanfilippo disease. $\beta$-Galactosidase (and $\alpha$-arabinosidase) are hypoactive (down to $15 \%$ of controls) in some cases, and normal in others.

\section{Chondroitin 4-Sulphaturia}

Chondroitin 4-sulphate is the major normal urinary mucopolysaccharide (Varadi, Cifonelli, and Dorfman, 1967) and its excretion remains normal in most cases of mucopolysaccharidosis. Philippart and Sugarman (1969), Campailla and Martinelli (1969),
Spranger, Schuster, and Freitag (1971), and Thompson, Nelson, Castor, and Grobelny (1971) have described cases with massive chondroitin 4-sulphaturia. The disease is usually well tolerated. Growth retardation is marked and other clinical data resemble those in the Scheie syndrome.

Ultrastructural alterations are the same as in Hurler disease (Freitag, Küchemann, Schuster, and Spranger, 1971c). Brain tissue has not yet been examined.

Liver acid hydrolases were assayed in two cases. $\beta$-Galactosidase (and $\alpha$-arabinosidase) had approximately $50 \%$ of the mean normal activity. Some of the other lysosomal enzymes were hyperactive, 


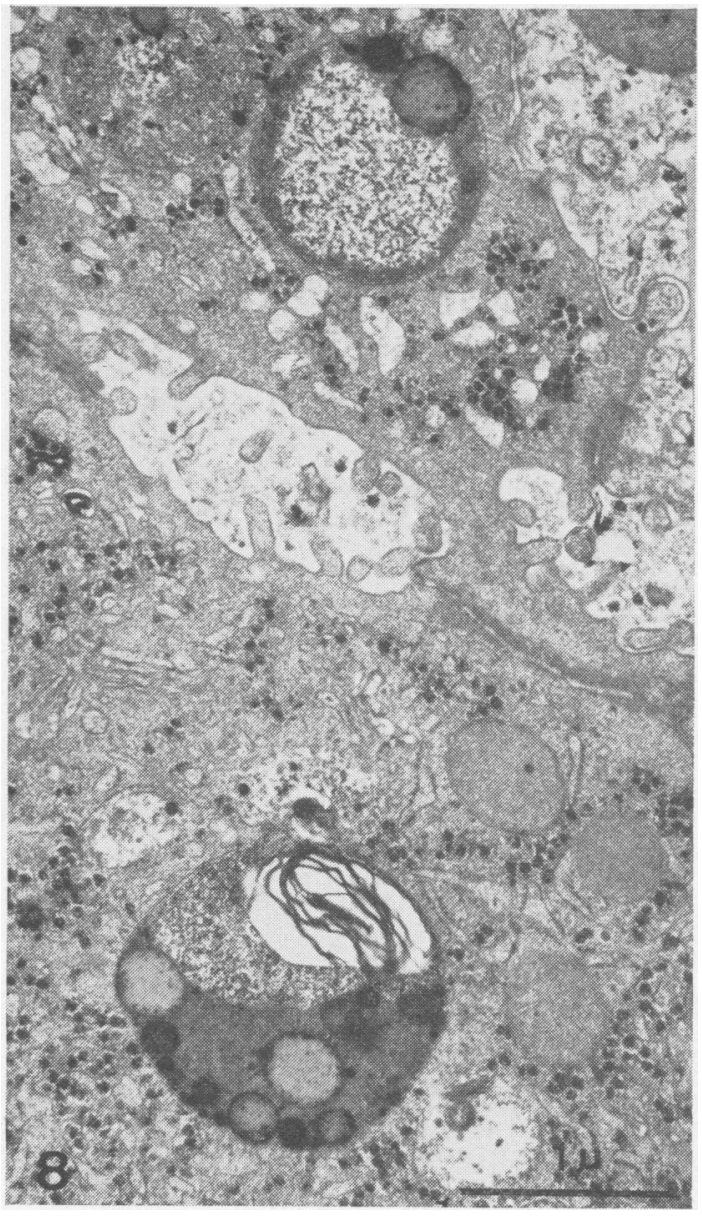

Fig 8 Hepatocytes in Maroteaux-Lamy disease. Secondary lysosomes are visible on both sides of bile canaliculi. They are only moderately enlarged. Part of the constituents of the matrix is normal in these dense bodies, which contain, in addition, densely granular material, and sometimes pseudo-myelin figures.

mainly $\beta$-hexosaminidase (eight times as active as in controls), $\alpha$-fucosidase, $\beta$-glucuronidase and $\beta$ glycerophosphatase, with a five-fold increase (Van Hoof, 1973a). The causal lesion remains unknown.

\section{Chondroitin 6-Sulphaturia}

This syndrome has been described by Schimke, Horton, and King (1971) in a 6-year-old girl. This patient suffered from a Hurler-like syndrome without hepatosplenomegaly. In addition she had lymphopenia, defective cellular immunity, and a nephrotic syndrome. Daily urinary excretion of acid mucopolysaccharides amounted to about $100 \mathrm{mg}$, almost exclusively chondroitin 6-sulphate. This remains an isolated observation and no ultrastructural or enzymatic data have been reported.

\section{$\beta$-Glucuronidase Deficiency}

This disease has been recognized in two patients only. One is a boy with a Hurler-like syndrome involving short stature, hepatosplenomegaly, dysostosis multiplex, and granular metachromatic inclusions in granulocytes (Sly, Quinton, McAlister, and Rimoin, 1973). Mental retardation and corneal opacities were absent. Mucopolysacchariduria, measured on different occasions, was either slightly elevated or at the upper limit of normal. Excreted mucopolysaccharides were chondroitin 4- and 6-sulphate. The other case, reported by Beaudet, Di Ferrante, Nichols, and Ferry (1972), is a 14-month-old girl, presenting with severe mental, motor, and growth retardation, hepatosplenomegaly, ascites, inguinal herniae, gibbus, corneal clouding, and metachromatic inclusions in granulocytes. Mucopolysacchariduria was normal in absolute value, but the ratio of high to low molecular weight glycosaminoglycans was very high. 4-Methylumbelliferyl- $\beta$-D-glucuronidase was undetectable.

Cultured fibroblasts, studied by E. Neufeld's group (Hickman and Neufeld, 1972; Hall, Cantz, and Neufeld, 1973; Neufeld and Cantz, 1973), are almost completely deficient in $\beta$-glucuronidase. As in other types of mucopolysaccharidoses, cultured fibroblasts from patients accumulate large amounts of radioactive polysaccharides, when radioactive sulphate is added to the culture medium. This accumulation can be corrected by the addition of bovine $\beta$-glucuronidase to the medium. Correction was also achieved by Lagunoff, Nicol, and Pritzl (1973) in fibroblasts from the patient of Beaudet et al (1972) using human enzyme purified from liver. When taken up by the cells the enzyme had a half life of more than 20 days.

$\beta$-Glucuronidase deficiency was demonstrated in patients' leucocytes. About $50 \%$ of the normal activity was found in the white blood cells of both parents of the first patient; the same deficiency was also found in leucocytes from five of the nine siblings of the mother (Sly et al, 1973). $\beta$-D-Glucuronidase is a lysosomal enzyme (de Duve $e t a l, 1955)$ and so this deficiency is another lysosomal storage disease.

\section{Mucolipidosis Type I}

This still imperfectly defined syndrome has been diagnosed in about 10 patients. The first cases were reported by Wiedemann and Spranger (1968) and by Spranger, Wiedemann, Tolksdorf, Graucob, and 
Caesar (1968) under the name of lipomucopolysaccharidosis. The quite characteristic ultrastructural alterations of the lysosomes were identical with those found at the same time by Loeb, Tondeur, Toppet, and Cremer (1969d) in two siblings suffering from an unclassifiable Hurler-like syndrome. Acid hydrolases had been analyzed in liver biopsies from Loeb's patients and $\beta$-galactosidase had been found to be astonishingly hyperactive; the syndrome had therefore been named 'mucopolysaccharidosis Gal +' (Van Hoof and Hers, 1968a; Van Hoof, 1970). After comparison of the findings of both groups Spranger and Wiedemann allowed us to measure liver acid hydrolases in most of their patients in whom $\beta$ galactosidase was also found to be hyperactive. Spranger and Wiedemann then suggested (1969) that all the cases belonged to the same syndrome, which they renamed mucolipidosis type I (Spranger and Wiedemann, 1970a, 1970b).

Liver acid hydrolases have now been analyzed in seven cases (Van Hoof, 1972, 1973a). The mean $\beta$-galactosidase activity is five times greater than normal. The hyperactivity of other hydrolases, such as $\alpha$-fucosidase, $\beta$-hexosaminidase (seven-fold increase), $\alpha$-galactosidase and $\beta$-glucuronidase (sixfold increase) indicate lysosomal dilatation. Ultrastructure shows that the clear vacuoles frequently contain numerous osmiophilic droplets (Spranger et al, 1968; Loeb et al, 1969d; Freitag, Blümcke, and Spranger, 1971a; Van Hoof and Hers, 1972).

Clinically, the syndrome is less homogeneous. Gargoyle-like facial dysmorphism and Hurler-type dysostosis were always present but varied largely in extent. Some patients suffered from peripheral neuropathy with myelin degeneration (Spranger et al, 1968). Two had a cherry-red macular spot. Vacuolized lymphocytes were found in all cases. Bone marrow storage cells with vacuolated cytoplasm or containing metachromatic granules were observed in the patients of Spranger et al (1968). Deafness, excessive mucopolysacchariduria, and coarse granulations in cultured fibroblasts were inconstant findings. These large clinical and biological differences suggest that mucolipidosis type $I$ is not a well defined disease.

Recent findings by Tondeur (1973) on analysis of fibroblasts from the patients of Loeb et al (1969d) add further confusion. Cells did not contain large refringent inclusions, like those described by Spranger et al (1968), nor did they stain metachromatically. Their ultrastructure displayed, however, numerous small clear vacuoles. No excess of radioactive sulphate incorporation into mucopolysaccharides could be detected. Enzymological analysis revealed an important deficiency of $\alpha$-mannosidase. The possibility that these patients suffer from an unusual form of mannosidosis could therefore be suggested. Indeed, in the latter disease, liver cells contain large clear vacuoles and their acid $\beta$ galactosidase is hyperactive as in mucolipidosis type I. Recently, however, we demonstrated that urine from one of these patients contained $a$ mannosidase, normally active at $\mathrm{pH} 4.4$ and 6.0 , together with a five-fold excess of $a$-galactosidase and a two-fold excess of acid $\beta$-galactosidase and $\beta$-hexosaminidase.

\section{Mucolipidosis Type II}

In 1967, Leroy and DeMars reported the presence of unusual cytoplasmic granular inclusions in cultured fibroblasts from two patients with a Hurler-like syndrome. These characteristic fibroblasts were named inclusion-cells or 'I-cells' and the syndrome, I-cell disease. Maroteaux, Hors-Cayla, and Pont (1970) proposed the name of mucolipidosis type II.

\section{CLINICAL FEATURES}

These are usually evident from birth and recall the Hurler syndrome by the facial dysmorphism, skeletal dysplasia, stiffness of the joints, and thick skin. The abdomen is protuberant, herniae, hepatomegaly, and heart lesions are frequent, but less prominent than in Hurler disease. Mental retardation is severe. Growth, at first normal, slows down around 1 year of age and stops almost completely after the age of 2 . Corneal opacity and vacuolated lymphocytes have been noted in almost all cases (Leroy and DeMars, 1967; Leroy and Crocker, 1967; Maroteaux et al, 1970; Spranger and Wiedemann, 1970a and b; Leroy, Spranger, Feingold, Opitz, and Crocker, 1971; Tondeur, Vamos-Hurwitz, Mockel-Pohl, Dereume, Cremer, and Loeb, 1971; de Montis, Garnier, Thomassin, Job, and Rossier, 1972; Gilbert, Dawson, Zu Rhein, Opitz, and Spranger, 1973; Walbaum, Dehaene, Scharfman, Farriaux, Tondeur, Vamos-Hurwitz, Kint, and Van Hoof, 1973). Radiological skeletal findings are similar to those in the Hurler syndrome but usually appear earlier (Taber, Gyepes, Philippart, and Ling, 1973). As a rule mucopolysaccariduria is normal. The diagnosis rests essentially on the demonstration of I-cells.

\section{I-CELLS}

These are enlarged fibroblasts, which contain numerous dense inclusions, most evident on phase contrast microscopy. Their ultrastructural appearance was described by DeMars and Leroy (1967); Hanai, Leroy, and O'Brien (1971); Tondeur et al (1971); Van Hoof $(1972,1973 a)$ and Gilbert et al (1973) (see also fig 9). The content of these inclusions is variable, mostly depending on the time 


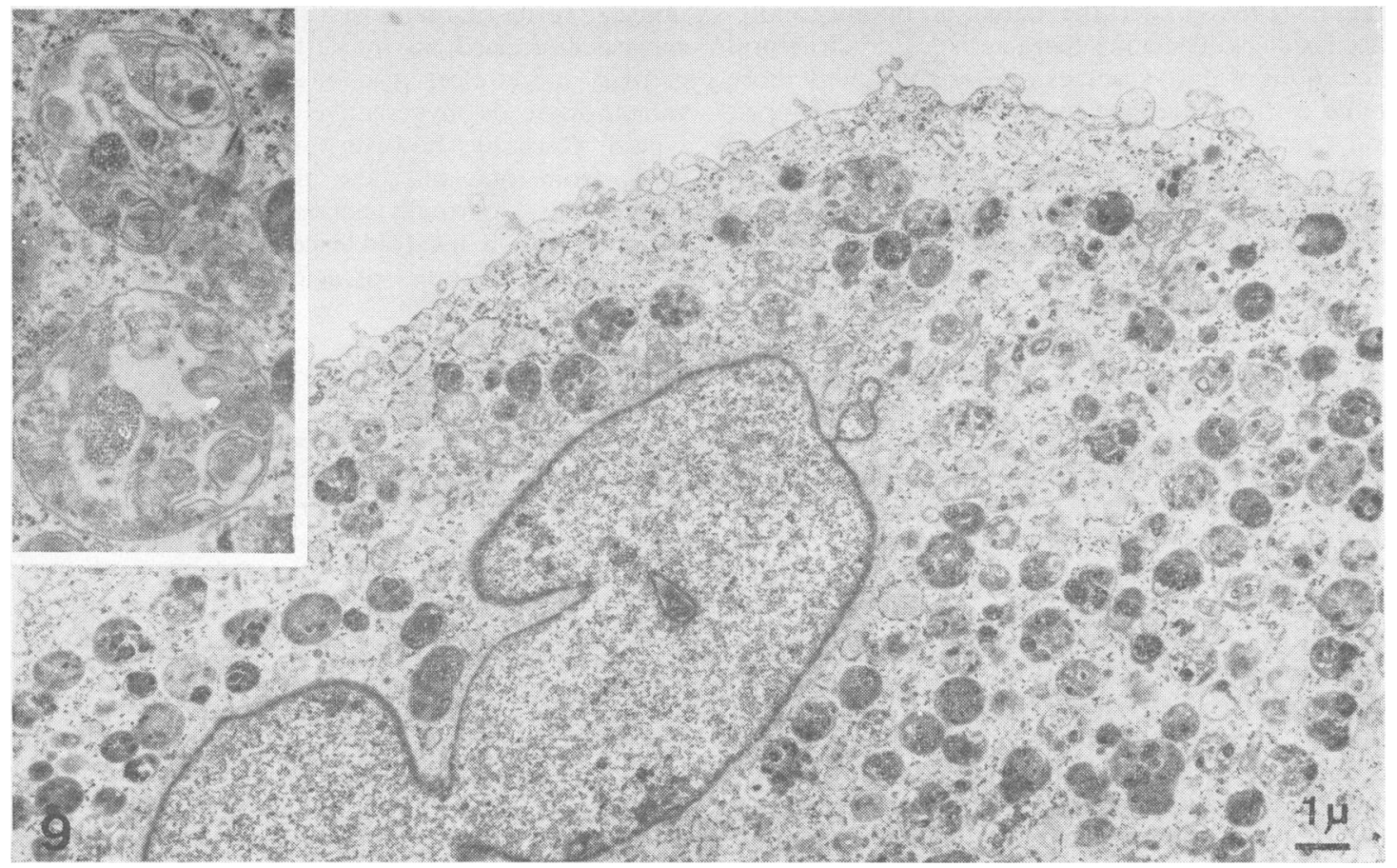

Fig 9 Cultured fibroblast in mucolipidosis II (I-cell). The cell is somewhat larger than fibroblasts from human controls; its cytoplasm is filled with more or less dense inclusions. The inset shows that these inclusions correspond to dilated lysosomes with polymorphic content. Autophagic debris, such as glycogen, ribosomes, membranes and sometimes partially digested mitochondria can be recognized in these lysosomes.

elapsed since the last subculture. At first relatively homogeneous and osmiophilic, the granules become progressively loaded with pleomorphic material strongly suggestive of defective digestion of autophagic residues (Van Hoof, 1972, 1973a). By all the evidence the inclusions are lysosomes. Morphometric analysis of electron micrographs indicates that lysosomes in I-cell disease are six times more numerous than in control fibroblasts, and that their diameter is about $60 \%$ larger than in controls. The relative volume occupied by lysosomes is thus increased from $1 \cdot 2 \%$ to $27 \%$ of the total cell volume.

The presence of I-cells in fibroblast cultures is not strictly pathognomonic of mucolipidosis type II. They can also be induced by adding antilysosomal antibodies (Tulkens, Trouet, and Van Hoof, 1970; see also fig 10) or chloroquine (Lie and Schofield, 1973) to the culture medium, or simply by buffering the medium at pH 8.6 (Lie, McKusick, and Neufeld, 1972; Lie, Schofield, Taylor, and Doty, 1973). Another interesting observation, made in fibroblasts from a patient of Dr J. Spranger, in Kiel, was the progressive appearance of I-cells after the fourth subculture (fig 11).

Chemical analysis of I-cells by Hof, Matalon, and Dorfman (1971) disclosed a two-fold increase of the lipid content of the cells. When fibroblasts were cultured in the presence of calf serum, lipid-bound neuraminic acid (gangliosides) and total haematoside were both approximately eight-fold more abundant in relation to the protein content than in normal cells. There was a similar eight-fold excess in $\mathrm{Gm}_{3}-$ and $\mathrm{GD}_{3}$-gangliosides. Dawson, Matalon, and Dorfman (1972) and Leroy, Ho, MacBrinn, Zielke, Jacob, and O'Brien (1972) confirmed the lipid accumulation, but found no abnormal storage of mucopolysaccharides in I-cells.

The first enzymatic studies of I-cells, by Leroy and DeMars (1967), indicated that $\beta$-glucuronidase activity was low but not totally absent. In addition, the activity of acid $\beta$-galactosidase, $\beta$-hexosaminidase, and $\alpha$-fucosidase was found deficient in fibroblasts from the patient reported, in 1968, by Matalon et al, who most probably suffered from mucolipidosis type II, according to Dorfman and Matalon (1972; 


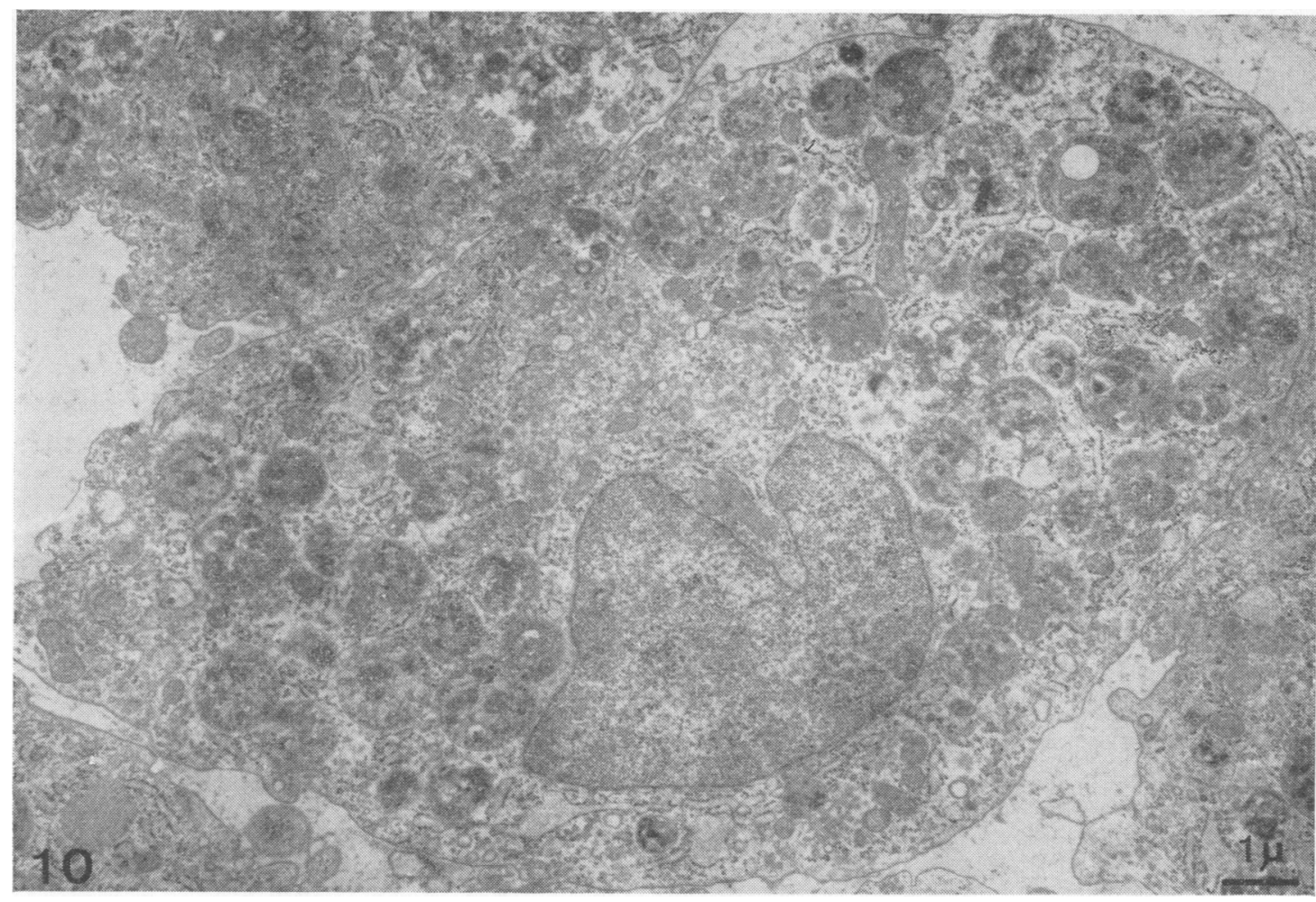

Fig 10 Rat fibroblasts ciltured in the presence of gammaglobulin from a rabbit immunized against the soluble constituents of purified rat liver lysosomes (Tulkens et al, 1970). Ultrastructural alterations are similar to those in I-cells.

Van Hoof, unpublished results). The fact that many lysosomal hydrolases are deficient in I-cells is now widely documented (Leroy and Spranger, 1970; Lightbody, Wiesmann, Hadom, and Herschkowitz, 1971; Tondeur et al, 1971; Leroy et al, 1972). Inhibition of some acid hydrolases was also demonstrated in fibroblasts in which I-cell-like lesions had been induced, as rat fibroblasts cultured in the presence of antibodies directed against the soluble constituents of lysosomes (Tulkens et al, 1970) and normal human fibroblasts cultured in a medium brought to pH 8 with TES buffer (Lie et al, 1972, 1973).

Different pathogenic interpretations have been proposed to explain this enzyme deficiency which involves several acid hydrolases. Wiesmann, Lightbody, Vassella, and Herschkowitz, (1971a) and Wiesmann, Vassella, and Herschkowitz (1971b) suggested that it results from leakage of acid hydrolases through abnormally permeable lysosomal membranes. To support this interpretation the authors stressed that acid hydrolases are much more abundant in the culture medium of I-cells than when control fibroblasts are grown. The argument was reinforced by the fact that acid hydrolases are also hyperactive in the serum of patients (Wiesmann et al, $1971 \mathrm{~b}$ ) and sometimes even of heterozygotes (Leroy and van Elsen, 1973). The suggested pathogenic mechanism does not take into account, however, that increased permeability of lysosomal membranes will first result in the leakage of acid hydrolases in the cytoplasm of the cell itself and, as a consequence, will damage the cell, as foreseen in the 'suicide bag' hypothesis (for a theoretical discussion, see Novikoff, 1973). In fact I-cells grow very well; dead cells are no more abundant in such cultures than when normal fibroblasts are grown.

An alternative explanation for the I-cell polyenzymatic deficiency was proposed by Hickman and Neufeld (1972). In contrast to Wiesmann et al (1971a and b) these authors suggest that acid hydrolases, although synthesized in normal amounts by I-cells, do not reach the lysosomes in sufficient amount because of some molecular imperfection. It is generally believed that acid hydrolases are synthesized at the level of the rough endoplasmic reticu- 


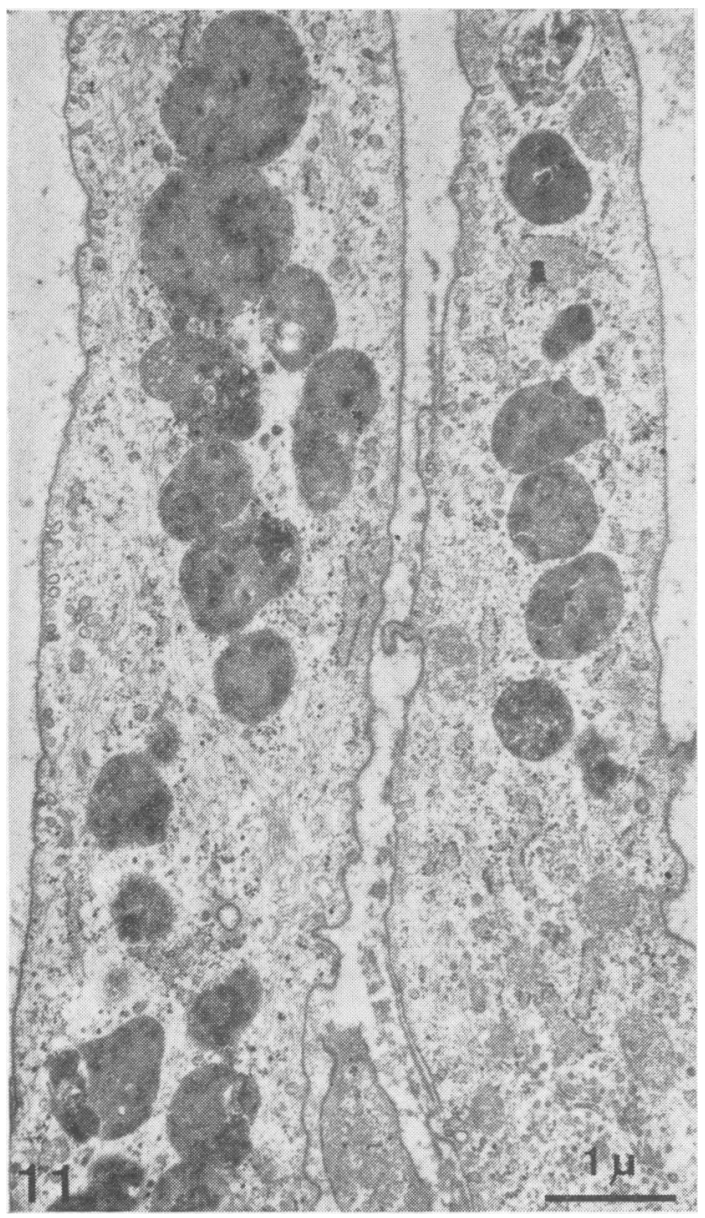

Fig 11 Cytoplasmic dense inclusions, similar to those in I-cells, appeared in fibroblasts from this patient, only after the fourth subculture. The patient, a boy studied by Dr J. Spranger in Kiel, is $6 \frac{1}{2}$ years old. He presents with skeletal dysplasia similar to that in mucolipidosis II and has a normal mucopolysacchariduria. Intelligence is, however, normal and corneae are clear. Cultured fibroblasts accumulate radioactive mucopolysaccharides when ${ }^{35} \mathrm{SO}_{4}$ is added to the medium, and are sensitive to all known corrective factors $(\mathrm{Dr} M$. Cantz, Kiel $)$. We measured 14 acid hydrolases in these cells. Most of them were hypoactive or even very deficient (mainly $\beta$-hexosaminidase and sulphatase $A$ ), while $\beta$ glucuronidase and $\beta$-xylosidase were distinctly hyperactive. Growth of the cells was at least $50 \%$ slower that that of controls. These fibroblasts have been fixed in situ and so appear elongated, in contrast to cells in fig 9, which were fixed after trypsinization, and were therefore rounded.

lum, concentrated in the Golgi apparatus, from which coated vesicles bud off (primary lysosomes) and later fuse with preexisting lysosomes or digestive vacuoles (for reviews, see Novikoff, 1963, 1973; de Duve and Wattiaux, 1966). The hypothesis of Hickman and Neufeld (1972) supposes another mechanism, at least in cultured fibroblasts, namely, that newly synthesized acid hydrolases are normally excreted in bulk from the Golgi apparatus into the culture medium. By means of a recognition site, perhaps an osidic group attached to the enzyme molecule (Neufeld, 1973), acid hydrolases should then be selectively reabsorbed by the cultured cells and reach the lysosomal apparatus by the way of endocytosis. I-cell disease is interpreted, in this view, as a defect of the specific marking of acid hydrolases.

In favour of this interpretation, Hickman and Neufeld (1972) report that acid hydrolases, like $\beta$ glucuronidase and $\beta$-hexosaminidase from the medium in which I-cells have been grown, are taken up much more slowly by normal and by $\beta$-glucuronidasedeficient cultured fibroblasts than are the same enzymes originating from control cells. Hickman and Neufeld's hypothesis also explains the presence in culture medium and the penetration in cells of 'corrective factors', which are lysosomal enzymes. The classical theory explains the presence of acid hydrolases in the extracellular medium by exocytosis or defaecation, processes believed to be fairly exceptional and restricted to certain types of cell such as osteoclasts (Vaes, 1968; Novikoff, 1973).

Some objections might be formulated against Hickman and Neufeld's theory. Its application to cells with poor endocytic capacity is difficult, and the authors recognize this themselves. On the other hand, the existence, in different types of cell, of different mechanisms of furnishing lysosomes with their enzymes is rather unlikely. It may also be stressed that the excretion of acid hydrolases into the culture medium, followed by their selective uptake, is not an economic process, since some lysosomal enzymes are inactivated rapidly in culture media at $\mathrm{pH} 7 \cdot 5$, as is human acid $\alpha$-glucosidase (de Barsy, unpublished data). Another consequence of Hickman and Neufeld's theory is that the lysosomal enzymes present in one cell may well originate from neighbouring fibroblasts. In cultures of fibroblasts from mothers of Hunter patients the Lyon hypothesis predicts that half of the cells will be affected by the $\mathrm{X}$-linked genetic lesion and will not synthesize iduronate sulphatase, while the other cells will be normal. If active intercellular exchange of acid hydrolases occurs there will be no detectable lesion in such cultures. On the other hand, if each cell is responsible for the synthesis of its own acid hydrolases, about $50 \%$ of the fibroblasts will develop metachromatic granules, and this is precisely what has been observed by Danes and Bearn (1966). 


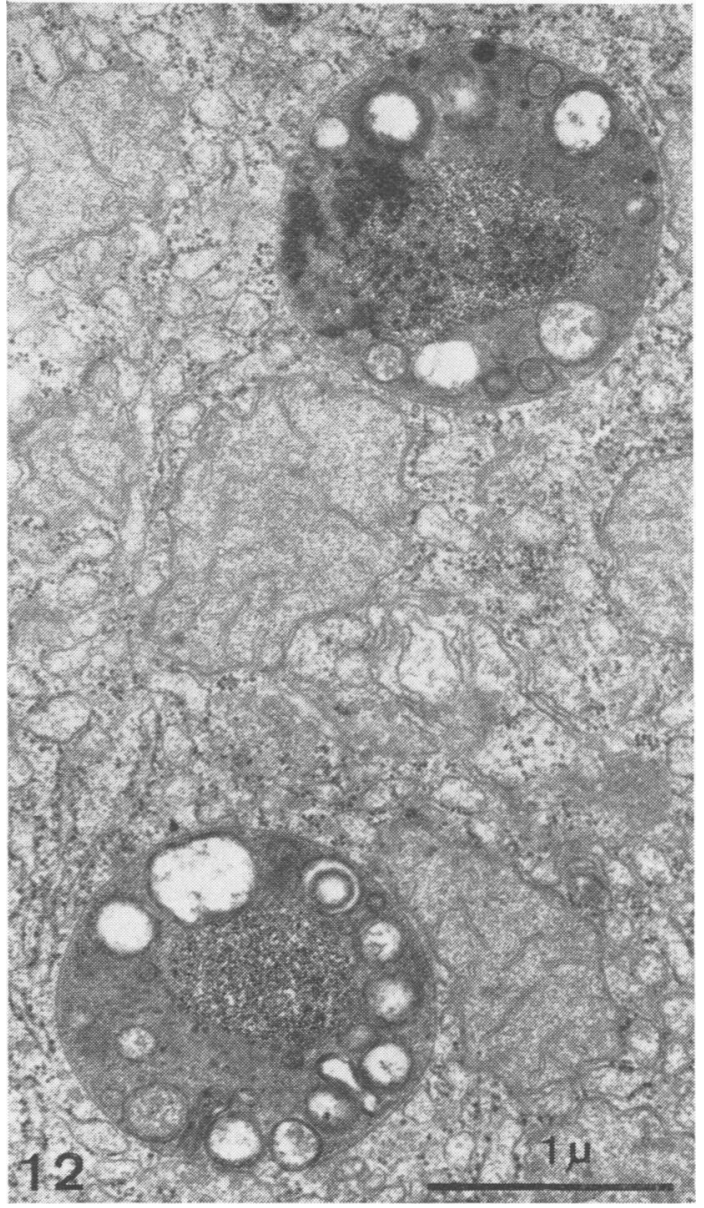

Fig 12 Hepatocyte in mucolipidosis type II. Moderately dilated lysosomes with polymorphic content. There is little, if any, indication that these organelles contain mucopolysaccharides.

ULTRASTRUCTURE OF VISCERAL TISSUES Liver ultrastructure is only moderately abnormal in mucolipidosis type II (fig 12). Some histiocytes, however, contain clear vacuoles. Similar lesions are found in kidney glomerular epithelial cells and in fibrocytes of the interstitial tissue, as well as in fibroblasts of the dermis, and in capillary pericytes and astrocytes (Tondeur et al, 1971). Ultrastructural alterations of fibroblasts in the dermis of patients is thus very different from that of the same cells in culture (I-cells).

CHEMICAL AND ENZYME INVESTIGATIONS IN VISCERAL TISSUES

No significant excess of lipids or of acid mucopolysaccharides has been demonstrated in liver, brain, kidney, or spleen from patients (Leroy et al, 1972; Van Hoof, 1972).

The enzymology of visceral tissues does not reflect the polyenzymatic deficiency characteristic of I-cells. Liver acid hydrolases measured in 13 cases displayed little significant abnormality (Van Hoof, 1972, 1973a). $\alpha$-Galactosidase and $\beta$-glycerophosphatase are usually hyperactive (about twice the control values) while acid $\beta$-galactosidase is hypoactive in most cases.

\section{Mucolipidosis Type III}

This rare syndrome was first outlined by Maroteaux and Lamy in 1966. Clinically it resembles the Hurler syndrome. Hepatosplenomegaly, light-microscopic changes in liver, vacuolated circulating white blood cells, and excessive mucopolysacchariduria are, however, lacking. $X$-ray examination reveals skeletal changes resembling the milder forms of the Hurler syndrome: these include claw hands, flattening of the femoral epiphyses, platyspondyly, and flaring of the iliac wings (Melhem, Dorst, Scott, and McKusick, 1973). Vacuolated cells are present in bone marrow, as in Hurler disease (Maroteaux and Lamy, 1966).

Ultrastructure of liver parenchymal cells shows only slightly enlarged secondary lysosomes, in which abnormal storage is not obvious (fig 13). Kupffer cells are relatively rich in unstructured osmiophilic materials. Cultured fibroblasts display somewhat enlarged lysosomes, which contain mostly lamellar and vesicular structures (fig 14). The cytoplasmic changes in these cells are much less important than in I-cell disease. Quigley and Goldberg (1971) reported the presence of clear vacuoles in conjunctival fibroblasts.

\section{GM $_{1}$-Gangliosidosis}

This disease was recognized in 1964 by Landing et al and called familial neurovisceral lipidosis; it was later named Landing's disease or generalized gangliosidosis, and was renamed when O'Brien, Stern, Landing, O'Brien, and Donnell (1965), Gonatas and Gonatas (1965), and Ledeen, Salsman, Gonatas, and Taghavy (1965) discovered the nature of the main accumulated lipid. Derry, Fawcett, Andermann, and Wolfe (1968) suggested that cases with later onset and moderate visceromegaly were suffering from a distinct form of $\mathrm{GM}_{1}$-gangliosidosis. Although presently widely accepted, this subdivision of the disease does not rest on undisputable enzymatic evidence (Suzuki, Crocker, and Suzuki, 1971; Van Hoof, 1973b). GM -Gangliosidosis has also been described in cats (Baker, Lindsey, McKhann, and Farrell, 1971; Handa and Yämakawa, 1971). 

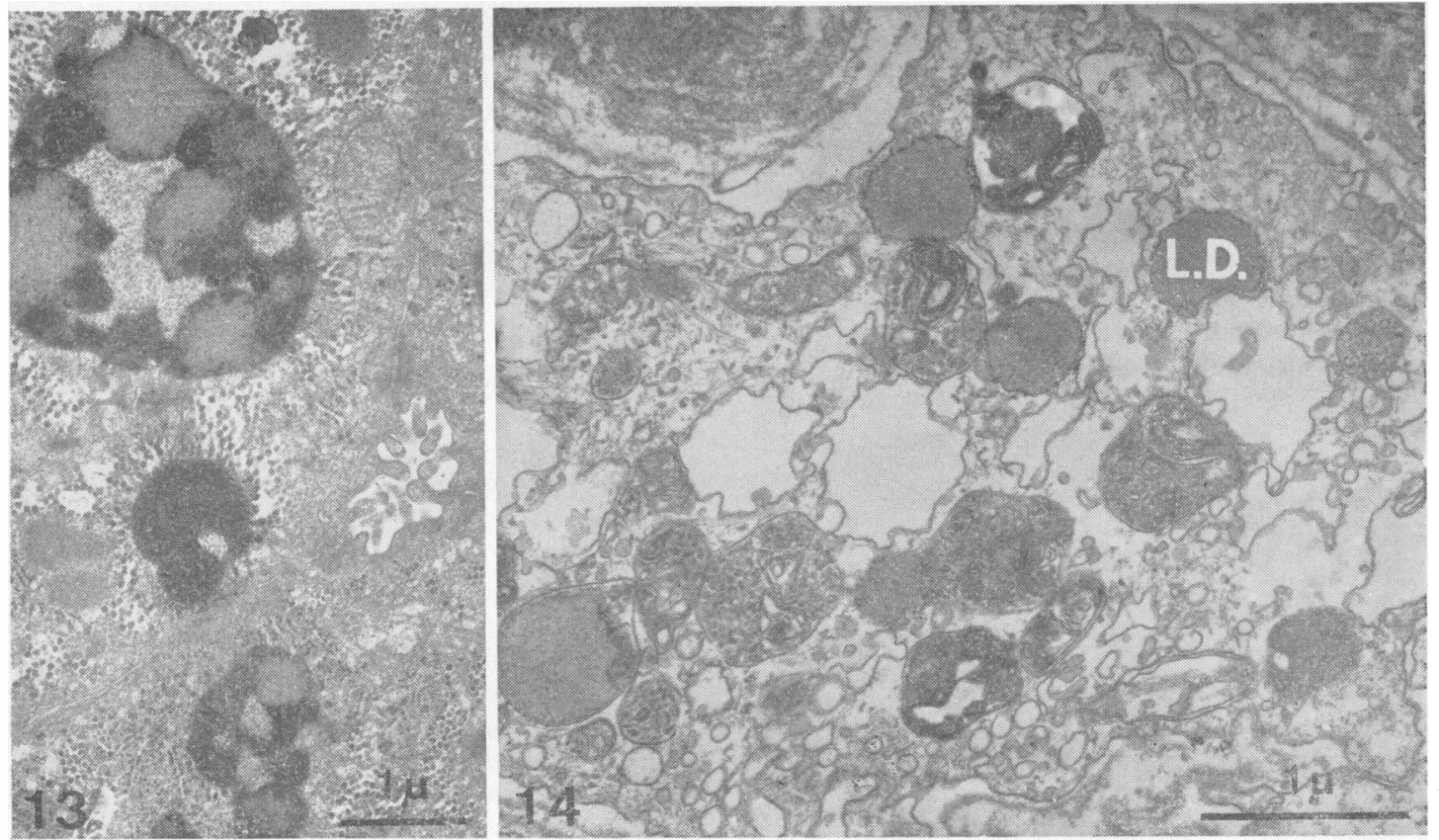

Fig 13 Mucolipidosis type III (patient no. 1 from Maroteaux and Lamy's original description of the syndrome).

Slightly enlarged lysosomes in the peribiliary area of hepatocytes. The content of these dense bodies is lipofuscin-like, except for some finely granular material.

Fig 14 Mucolipidosis type III, cultured fibroblast. Lysosomes contain lamellar material and numerous small vesicles ( $L D=$ lipid droplet $)$.

CLINICAL AND BIOLOGICAL DATA

In the early infantile form, symptoms may be present at birth and life expectancy is from one to two years. Some symptoms evoke an impression of the Hurler syndrome, especially the facial dysmorphism, macroglossia, skeletal deformities, and distended abdomen due to hepatosplenomegaly. Lung and upper respiratory tract infections are frequent. Circulating and bone marrow white blcod cells contain metachromatic vacuoles. Another part of the clinical picture suggests a lipidosis, such as the early impairment of psychomotor development, hypotonia followed by spasticity, convulsions, and amaurosis sometimes with macular cherry red spot. $X$-ray examination discloses the same skeletal deformities as in the Hurler syndrome. Mucopolysacchariduria is quantitatively normal, but an excess of keratan sulphate has occasionally been noted ( $R$. Humbel, personal communication).

In the late infantile form, symptoms were detected only between 6 months and $1 \frac{1}{2}$ years; death occurred between 3 and 10 years of age. Visceromegaly and $x$-ray abnormalities are minimal and the clinical picture is dominated by the progressive psychomotor disturbances. Seizures are frequent and usually resistant to anticonvulsant drugs. First hypotonic, the patients become spastic in the later stages of the disease. They usually die from intercurrent infections.

Clinical differences between the early and late infantile forms of $\mathrm{GM}_{1}$-gangliosidosis are not more important than the variations currently noted among patients suffering from type II glycogenosis (Hers and Van Hoof, 1968; Hers and de Barsy, 1973), from fucosidosis (see below), and from many other lysosomal storage diseases (Hers, 1973; McKusick, 1973).

\section{PATHOLOGY}

Landing, Silvermann, Craig, Jacoby, Lahey, and Chadwick (1964) showed that PAS-positive or sudanophilic material is present within cytoplasmic vacuoles in almost all organs. These authors concluded rightly from their histochemical approach that the lipid material, which accumulates mainly in nervous tissue, is ganglioside in nature. On the other hand, visceral organs are heavily loaded with metachromatic water-soluble materials but are poor in 


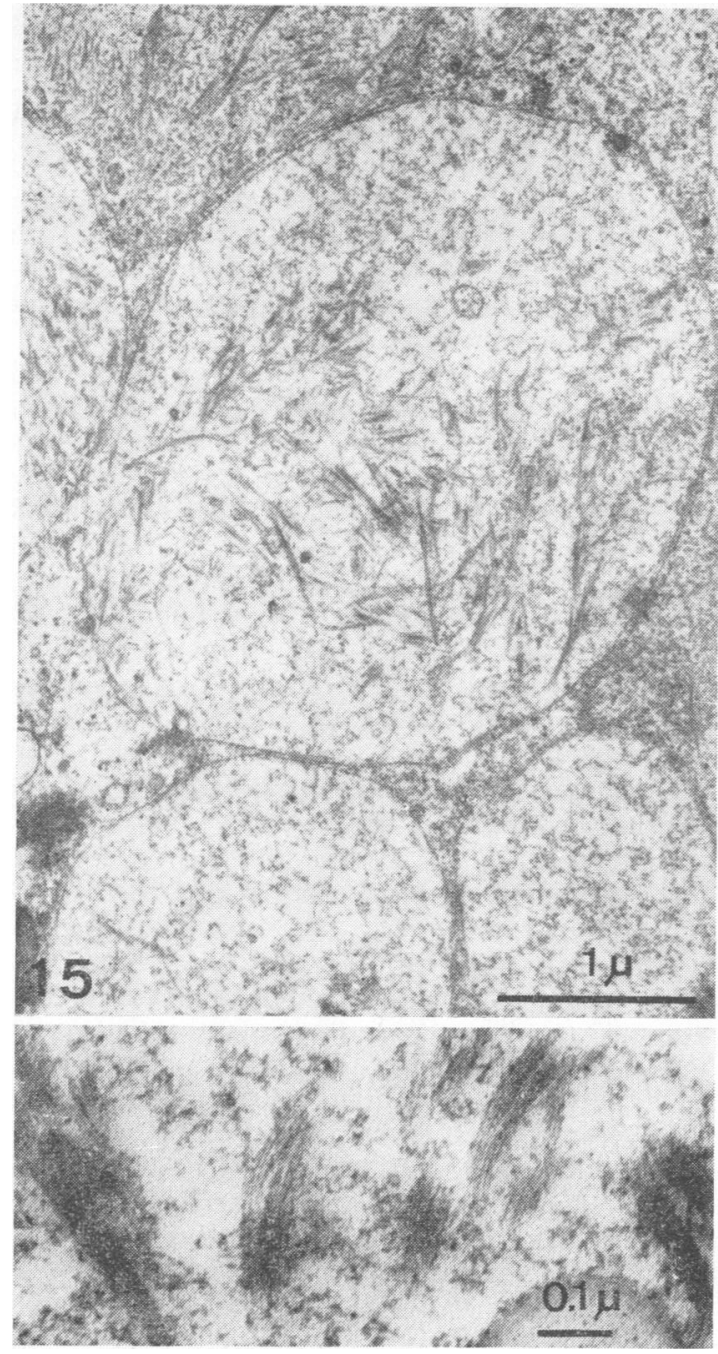

Fig $15 G \mathrm{M}_{1}$-Gangliosidosis. Detail of a Kupffer cell. Most of the cytoplasm is occupied by clear vacuoles, similar to those observed in the first three types of mucopolysaccharidosis, except for the presence within them of finely tubular or lamellar material (see enlargement, below).

sudanophilic substances, in the early infantile form of $\mathrm{GM}_{1}$-gangliosidosis. In the cases with later onset the liver overloading is moderate and seems to spare hepatocytes (Derry et al, 1968).

Ultrastructural studies disclose lesions similar to those in Hurler disease: lamellar inclusions in neuronal lysosomes, first described by Gonatas and Gonatas (1965), and clear vacuoles in visceral organs (Sacrez et al, 1967; Van Hoof and Hers, 1967b). Morphometric analysis of liver micrographs indicates that the lysosomal volume increases at least as much as in the Hurler syndrome, with an extreme diversity in the size of the vacuoles, a few lysosomes being barely affected while others may exceed 20 microns in diameter, with a volume approximately 50000 times that of dense bodies in control livers (Van Hoof, 1973a). Fine tubular elements, first reported by Suzuki, Suzuki, and Chen (1968 a and b), are frequently found in these vacuoles, especially in Kupffer cells (fig 15). As in the Hurler syndrome intestinal absorptive cells contain large lysosomes with a finely granular matrix, different from the clear vacuoles present in most types of cells (Daems et al, 1973; Ginsel et al, 1973).

\section{CHEMISTR Y}

The structure of the major lipid accumulating in tissues was recognized almost simultaneously by O'Brien et al (1965) and Ledeen et al (1965). GMGanglioside, or monosialo-ganglioside, constitutes approximately $90 \%$ of the ganglioside in the grey matter. In brain, its asialo-derivative is also in excess (Suzuki and Chen, 1967). Suzuki, Suzuki, and Kamoshita (1969) have isolated from the brain of patients the lipid-laden lysosomes: $95 \%$ of their ganglioside content was found to be $\mathrm{Gm}_{1}$-ganglioside. This substance and its asialo-derivative contain $\beta$-galactose as terminal osidic residue.

Polysaccharides accumilate in much larger amounts, mostly in visceral tissues. This was suggested from ultrastructural data (Sacrez et al, 1967; Van Hoof and Hers, 1967b) and proved by chemical analysis (Suzuki, 1968; Suzuki et al, 1969). Most of the stored material has the composition of parially desulphated keratan sulphate; it is rich in galactose. A lesser fraction, called by Suzuki et al (1969) sialomucopolysaccharide, contains in addition sialic acid and traces of mannose. It is probable that these polysaccharides originate from both keratan sulphate and glycoproteins.

\section{ENZYMOLOGY}

$\mathrm{GM}_{1}-\mathrm{Gangliosidosis}$ results from the total absence or profound deficiency of acid $\beta$-galactosidase (Van Hoof and Hers, 1968a), as first demonstrated in the case reported by Sacrez et al (1967). The enzyme defect, confirmed by Okada and O'Brien (1968, 1969), is generalized and can be detected in tissues, in plasma or white blood cells, and in urine. Only the most acid form of $\beta$-galactosidase is affected; activities recorded at pH 6.5 or 9 are approximately normal. Acid $\beta$-galactosidase is a lysosomal enzyme, as demonstrated in rat liver (Sellinger, Beaufay, Jacques, Doyen, and de Duve, 1960), and spleen (Bowers and de Duve, 1967). MacBrinn, Okada, Ho, Hu, and O'Brien, (1969) have shown that the tissues 
of patients contain almost no $\beta$-galactosidase able to hydrolyse not only $\mathrm{GM}_{1}$-ganglioside and synthetic substrates, but also the keratan sulphate-like material isolated from livers of patients, or desialated fetuin. Acid $\alpha$-arabinosidase is also barely active and sometimes totally absent.

Many acid hydrolases are hyperactive in $\mathrm{GM}_{1-}$ gangliosidosis. In liver, $\mathrm{N}$-acetyl- $\alpha$-galactosaminidase is about 12 times more active than in controls, $\alpha$ galactosidase eight-fold, $\beta$-hexosaminidase sevenfold, and many other glycosidases, to a lesser extent (Van Hoof, 1973b). The reason for these secondary enzyme hyperactivities is probably the same as in the Hurler syndrome.

Prenatal detection has been achieved in GM1gangliosidosis. The amniotic fluid has been found totally deprived of (Lowden, Cutz, Conen, Rudd, and Doran, 1973) or deeply deficient in acid $\beta$ galactosidase (Kaback, Sloan, Sonneborn, Herndon, and Percy, 1973). These two groups of authors have shown that cultured amniotic cells have less than $5 \%$ of the normal $\beta$-galactosidase activity, and that the tissues of affected fetuses, aged 17 and 21 weeks, already displayed the ultrastructural alterations which characterize the disease.

\section{Fucosidosis}

The clinical syndrome corresponding to fucosidosis was recognized by Durand, Borrone, and Della Cella (1966) and reported under the title 'A new mucopolysaccharide-lipid storage disease?'. Liver ultrastructure was typical in the two original patients (Van Hoof and Hers, 1967b) and allowed the recognition of a third case (Loeb, Tondeur, Jonniaux, Mockel-Pohl, and Vamos-Hurwitz, 1969b; Loeb, Tondeur, Résibois, Jonniaux, and Van Hoof, 1969c). The discovery of the enzyme defect (Van Hoof and Hers, 1968a and b) helped to unravel the nature of the stored substances: fucose-containing polysaccharides and glycolipids.

\section{CLINICAL FEATURES}

These are difficult to summarize, so large are their variations. Eight cases have been reported in children: two by Durand et al (1966), Durand, Philippart, Borrone, Della Cella, and Bugiani (1967), Durand, Borrone, and Della Cella (1969a), Durand, Phillipart, Borrone, and Della Cella (1969b), one by Loeb et al (1969b and c), one by Freitag et al (1971b), Voelz, Tolksdorf, Freitag, and Spranger (1971), two siblings, patients of $\mathrm{Dr}$ Donnell of Los Angeles, reported by Zielke, Veath, and O'Brien (1972), one in Japan by Matsuda, Arashima, Anakura, Ege, and Hayata (1973), and one by Borrone, Gatti, Trias, and Durand (1974).
These patients present with more or less marked Hurler-like features such as bone deformities, hepatosplenomegaly, thickness of the skin, tendency to herniae, and heart enlargement. Neurological changes are prominent in some cases and minimal in others. Death occurs usually between 4 and 6 years of age. Circulating white blood cells are vacuolated, but there is no excessive mucopolysacchariduria. The concentration of sweat electrolytes has occasionally been elevated.

Four further cases, with slower evolution and presenting with angiokeratoma corporis diffusum, have recently been reported. The first, now 21 years old, has severe physical and mental retardation: he was never able to walk or talk. The face shows gargoyle features. From the age of 4 , he suffered from clinical angiokeratoma corporis diffusum, which pointed the diagnosis toward Fabry disease. $\alpha$-Galactosidase, however, was normal, while $\alpha$-Lfucosidase activity was less than $10 \%$ in leucocytes and urine (Patel, Watanabe, and Zeman, 1972; Epinette, Norins, Drew, Zeman, and Patel, 1973). Another case, reported by Gatti, Borrone, Trias, and Durand (1973) and by Borrone et al (1974), is a 17year-old boy. He also has a long history of somatic and psychomotor retardation, recognized around the age of 1. Angiokeratoma corporis diffusum appeared when he was 5-6 years old. He now presents with spasticity and Hurler-like features, but without visceromegaly. $\alpha$-Fucosidase activity was $5 \%$ of the controls in serum and $7 \%$ in leucocytes. Two brothers, aged 9 and $4 \frac{1}{2}$ years respectively, have recently been briefly reported by Kousseff, Beratis, Danesino, and Hirschhorn (1973) with a similar clinical picture: mild facial and bone dysplasia, slowly progressive psychomotor retardation, and angiokeratoma corporis diffusum. There were neither hepatosplenomegaly nor corneal opacities. $a$-Fucosidase was severely deficient in cultured fibroblasts.

Repeated respiratory infection has been noted in practically all cases of fucosidosis.

\section{PATHOLOGICAL DATA}

Gross pathological and light microscopic lesions in patients with the severe form of the disease are reminiscent of the Hurler syndrome with, in addition, a strawberry-like alteration of the gallbladder. Another difference is that brain neurones accumulate little lipid, but instead a PAS-positive material, soluble in water and resistant to amylase, while visceral tissues contain substantial lipid as well as polysaccharide deposits.

Ultrastructure of liver is quite typical (fig 16). Cytoplasmic clear vacuoles, which correspond to lysosomes dilated by polysaccharide, frequently 


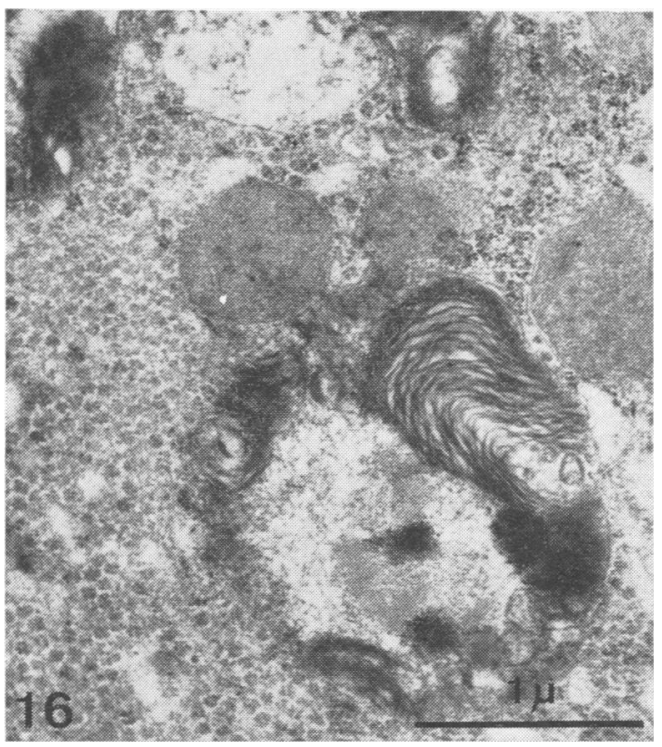

Fig 16 Fucosidosis. Lysosomes in liver parenchymal cells contain finely granular material, suggesting the presence of polysaccharide substances, and lamellar structures indicating the accumulation of complex lipids.

Fig 17 Fucosidosis. Clear vacuoles, some of them containing lamellar material, surround the nucleus of this cultured fibroblast.

contain large amounts of complex lipids, which appear as lamellated osmiophilic structures (Van Hoof and Hers, 1967b; Van Hoof, 1973c). Both types of material are contrasted by silver nitrate after periodic acid oxidation (Loeb et al, 1969b), indicating the presence of vicinal glycol groups. Brain neurones contain numerous cytoplasmic clear vacuoles and only rarely membranous material (Loeb et al, 1969b; Résibois, Tondeur, Mockel, and Dustin, 1970). Cultured skin fibroblasts are rich in clear vacuoles that often contain lamellar inclusions (fig 17). In the adult patient reported by Patel et al (1972) and Epinette et al (1973) clear vacuoles were present in fibroblasts, in keratinocytes, and in capillary endothelial cells.

Chemical studies disclose the presence in tissues of different types of fucosides. From liver tissue, a water-soluble fraction, precipitable in the presence of cetylpyridinium chloride after proteolytic digestion, was extracted by Van Hoof and Hers (1968a). This fraction, considered to be mucopolysaccharide, contained significant amounts of fucose. Philippart (1969) isolated from livers of the same patients glycopeptides and oligosaccharides, both containing fucose and displaying antigenic activity of the $\mathrm{Le}^{\mathrm{a}}$ type. Different fucose-containing glycolipids were

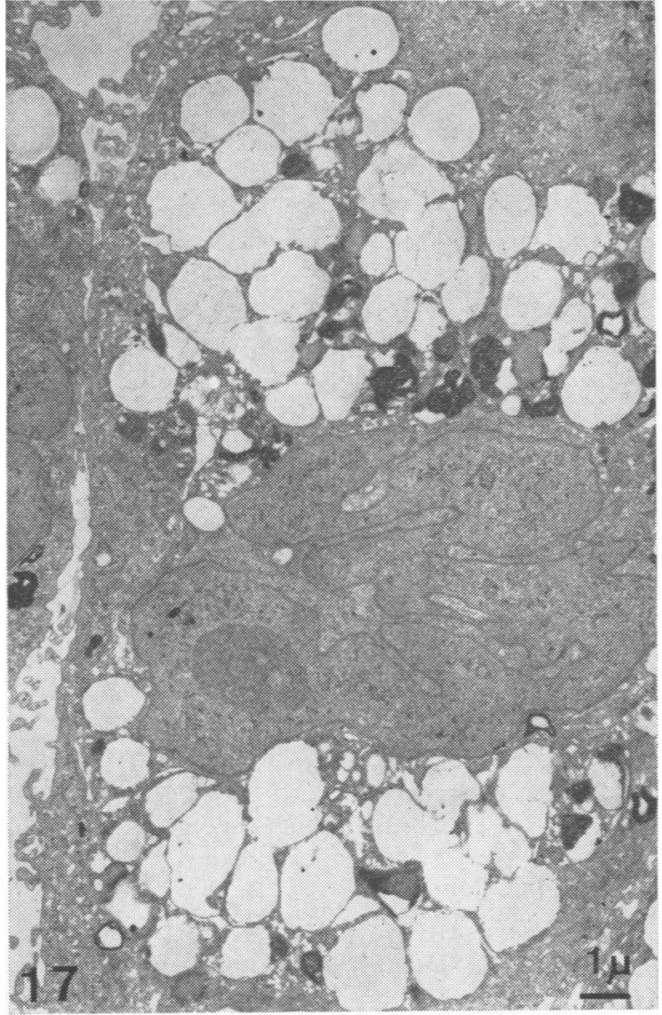

extracted from patient's tissues (Durand et al, 1967; Durand, Borrone, Della Cella, and Phillipart, 1968; Philippart, 1969, 1972; Loeb et al, 1969b; Dawson and Spranger, 1971; Voelz et al, 1971; Dawson, 1972). These ceramide tetra- and pentasaccharides disclose $\mathrm{H}$ and $\mathrm{Le}^{\mathrm{a}}$ antigenicity.

\section{ENZYMOLOGY}

Fucosidosis is due to a total defect (Van Hoof and Hers, 1968a and b) or a profound deficiency of $a-\mathrm{L}$ fucosidase. The defect has been confirmed in all the tissues tested, as well as in plasma and urine. The recent introduction by Koch-Light Ltd (Colnbrooks, Bucks) of a fluorogenic substrate has rendered $a$ fucosidase assay both easy and extremely sensitive. $a$-L-fucosidase is a lysosomal enzyme. This could be deduced from the data of Conchie and Hay (1963) and has been verified in rat liver after injection of Triton WR-1339 (Van Hoof, 1973c).

Many other lysosomal hydrolases are hyperactive in fucosidosis. The largest hyperactivities in liver concern $\mathrm{N}$-acetyl-a-galactosaminidase (over six times the controls), $\alpha$-galactosidase and $\beta$-xylosidase (over five times), $\alpha$-glucosidase and palmitate ester- 
ase, over four times the normal value (Van Hoof, 1973c).

Prenatal diagnosis has, to our knowledge, never been achieved, but is feasible since amniotic fluid and cultured amniotic cells contain $\alpha$-fucosidase. We have, however, frequently noted that the enzyme disappears from fibroblasts after repeated subcultures. If this occurs also with cultured amniotic cells, it could result in a false diagnosis.

Heterozygote detection has been attempted by Borrone et al (1974) by measuring $a$-fucosidase in serum and leucocytes.

\section{Mannosidosis}

Mannosidosis, like fucosidosis, was discovered by systematic analysis of lysosomal enzymes in patients. The first case was recognized by Öckerman in 1967, and five additional patients were reported in 1973. Mannosidosis was also diagnosed in Angus cattle (Jolly, 1970, 1971; Hocking et al, 1972; Jolly and Blakemore, 1973). The disease has been carefully studied by ultrastructural and enzymatic analyses, and large-scale detection of heterozygote calves has been achieved.

\section{CLINICAL FEATURES}

These recall the Hurler syndrome and sometimes aspartylglycosaminuria and begin during the first year of life. They include moderate facial dysmorphism, with prominent forehead and protruding tongue, corneal opacities (usually discrete), vertebral deformities, hepatosplenomegaly and slowly progressive psychomotor retardation. These patients are also abnormally susceptible to infection. The original patient died at the age of $4 \mathrm{yr} 4 \mathrm{mth}$; the other patients were still alive in 1973, the oldest aged 10 (Öckerman, 1967, 1973; Nordén, Öckerman, and Szabo, 1973b).

\section{LABORATORY FINDINGS}

These include the presence in peripheral blood and bone marrow of vacuolated lymphocytes and, in urine, of mannose-rich oligosaccharides. Mucopolysacchariduria is normal.

Morphological analysis discloses ballooning of neurones throughout the central nervous system and the spinal cord. Lymph node and spleen lymphocytes are also heavily loaded with PAS-positive, water-soluble substances. Liver ultrastructure is quite similar to that in Hurler disease, with large clear vacuoles (Ormos, Monus, Szabo, and Csapo, 1971; Rapola, 1972).

Water extracts from liver and brain contain a large excess of mannose, while no excess of mannose could be demonstrated in the lipids extracted from these tissues. Analysis of the mannose-rich compounds indicates a predominance of oligosaccharides with three to eight residues and deprived of uronic acid, which are probably residues of glycoprotein digestion. Minor mannose-containing fractions were macromolecular or were retained by anion-exchange chromatography (Öckerman, 1969, 1970, 1973). Urinary oligosaccharides rich in mannose are of diagnostic value (Öckerman, Nordén, and Szabo, 1972; Nordén, Eriksson, Hultberg, and Öckerman, 1973a; Nordén et al, 1973b).

\section{ENZYME STUDIES}

All $\alpha$-mannosidase activity is not absent from tissues of patients (Öckerman, 1967). DEAE-cellulose chromatography separates three forms of liver $a$ mannosidase, two are maximally active at $\mathrm{pH} 4 \cdot 4$, and a third has an optimal pH of 6.0. The first two forms only are lacking in patients (Carroll, Dance, Masson, Robinson, and Winchester, 1972). Acid $\alpha$ mannosidase is a lysosomal enzyme (Conchie and Hay, 1963; Bowers and de Duve, 1967). Some other acid hydrolases are hyperactive in mannosidosis: in liver, for instance, $\mathrm{N}$-acetyl $\beta$-hexosaminidase, $\beta$ glucuronidase, $\beta$-galactosidase, $\alpha$-glucosidase, and $\alpha$ fucosidase activities are frequently increased more than three-fold (Öckerman, 1967; Rapola, 1972; Nordén et al, 1973b).

\section{Mucosulphatidosis}

This rare disease was first recognized by Austin (1965) in two siblings, brother and sister, presenting with a late infantile metachromatic leucodystrophy associated with signs of gargoylism. Many descriptive names have been used, from 'link with gargoylism' (Austin, 1965), to 'metachromatic leucodystrophy variant', 'trisulphatase or multiple sulphatase deficiency' (Austin, 1973a and b). The name of 'mucosulphatidosis' was proposed by Rampini, Isler, Baerlocher, Bischoff, Ulrich, and Plüss (1970).

\section{CLINICAL AND BIOLOGICAL FEATURES}

These are reminiscent of both mucopolysaccharidosis and sulphatidosis (metachromatic leucodystrophy). A somewhat coarse facial appearance, minor bone dysplasia, mild hepatosplenomegaly, excessive mucopolysacchariduria, vacuolated white blood cells in bone marrow and in circulating blood, together with the Alder granulation abnormality, point the diagnosis towards the mucopolysaccharidoses. On the other hand, the evolution of the neurological defect, increased CSF protein, reduced nerve conduction velocity, and the presence of goldenbrown metachromatic granular bodies in urine are signs of metachromatic leucodystrophy. The disease 
becomes evident around 1 year of age and death occurs between 3 and 12 years (Austin, 1965, 1973a and b; Thieffry, Lyon, and Maroteaux, 1967; Bischoff and Ulrich, 1967; Rampini et al, 1970; Murphy, Wolfe, Balazs, and Moser, 1971).

\section{PATHOLOGICAL FINDINGS}

These include atrophy of brain and cerebellar cortex with thickening of meninges. Cardiac valvular nodules may be present as in the Hurler syndrome. In contrast to metachromatic leucodystrophy, no alteration in the gallbladder has been reported.

Light microscopy discloses in most tissues the presence of pigments (sulphatides) with a metachromatic golden-brown colour after staining with cresyl violet, according to von Hirsch and Peiffer (1955). Liver, spleen, and kidney also contain watersoluble material which stains metachromatically with

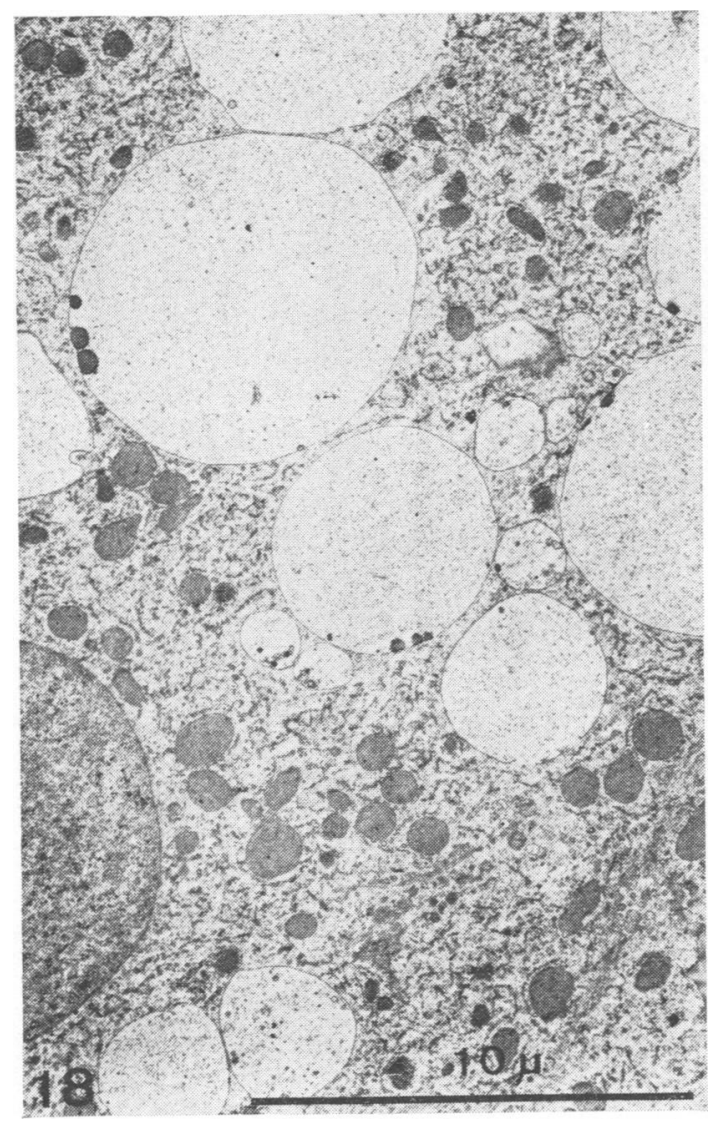

Fig 18 Mucosulphatidosis. The cytoplasm of hepatocytes (and Kupffer cells) contains clear vacusles, bonded by a single membrane, as in mucopolysaccharidosis types I-III. All dense bodies have disappeared. toluidine blue (mucopolysaccharides).

The ultrastructure of the liver is practically indistinguishable from that in the Hurler syndrome (Van Hoof and Hers, 1972; Van Hoof, 1973a, see also fig 18). Similar alterations were found in fibroblasts from kidney interstitial tissue, while cells of the distal tubules contain, as in sulphatidosis, prismatic stacks of lipid leaflets (Tondeur, 1973). Ultrastructural alterations in peripheral nerve cells are the same as in metachromatic leucodystrophy (Bischoff and Ulrich, 1967). Small clear cytoplasmic vacuoles are present in lymphocytes and cultured fibroblasts (Lyon, Hors-Cayla, Jonsson, Maroteaux, 1973).

The mucopolysaccharides excreted in urine are a mixture of heparan and dermatan sulphate (Rampini et al, 1970). Not all cases, however, have a significant excess of mucopolysacchariduria (Austin, 1973a; R. Humbel, personal communication). Tissue mucopolysaccharides are rich in sulphate groups. In liver, their accumulation is of the same order of magnitude as in the Hurler syndrome (Murphy et al, 1971; Austin, 1973a), and Austin stresses that mainly $O$-sulphated mucopolysaccharides are found, which is likely to be due to deficiency of an $O$-sulphatase rather than a sulphamatase.

Sulphatides are also present in great excess. Cerebroside 3-sulphate represents $26 \%$ of kidney lipid, a value similar to that found in patients with metachromatic leucodystrophy. A large excess of cholesterol sulphate was detected in liver, kidney, plasma, and urine (Murphy et al, 1971).

\section{ENZYMOLOGY}

Mucosulphatidosis results from a marked deficiency of sulphatase activity.

Arylsulphatase A, a lysosomal enzyme (Viala and Gianetto, 1955), is practically inactive in brain, liver, kidney, urine (Austin, 1965), and leucocytes (Van Hoof, 1972). The enzyme protein, however, can be demonstrated immunologically (Austin, 1973a and b).

The activity of arylsulphatase B, also lysosomal (Roy, 1958), is markedly decreased in brain and kidney (Austin, 1965). In two recent cases, we found it to be approximately $25 \%$ in liver and, in brain, $50 \%$ of the normal activity.

The microsomal (Roy, 1958) sulphatase C, optimally active near neutral $\mathrm{pH}$ on p-nitrophenylsulphate, is also markedly reduced in mucosulphatidosis (Austin, 1965, 1973a and b; Murphy et al, 1971). The inability of the patient's tissues to hydrolyse steroid sulphates (Murphy et al, 1971; Moser, Sugita, Harbison, and Williams, 1972) or 4-methylumbelliferyl sulphate around neutral pH (Van Hoof, $1972,1973 a)$ are probably expressions of the sul- 
phatase $\mathrm{C}$ deficiency. In two recent cases we found liver methylumbelliferyl sulphatase at $\mathrm{pH} 7.4$ to be $13 \%$ and $14 \%$ of controls. PAPS-sulphatase appears relatively spared (Austin, 1973a and b).

The most probable explanation for this multienzyme deficiency is to assume a defect in the synthesis of a peptide chain common to the various hydrolases acting on sulphated substrates.

Other acid hydrolases have been measured in patients. $\beta$-Galactosidase activity is reduced in liver, kidney, cerebral cortex, leucocytes, and urine (Austin, 1965, 1973a and b; Murphy et al, 1971; Moser et al, 1972; Van Hoof, 1972, 1973a). Many other hydrolases are hyperactive, mostly $\beta$-hexosaminidase (about 10-fold the normal activity), $\alpha$ fucosidase and $\alpha$-mannosidase (about five-fold), in the cases we have studied.

\section{Other Related Disorders}

Several patients have been described as suffering from a 'mucopolysaccharidosis without mucopolysacchariduria', or presenting with uncommon features so that they could not be classified among the known mucopolysaccharidoses or mucolipidoses (see, for instance, Gollance and d'Amico, 1967; Marchal, Grignon, Humbel, Vidailhet, Fall, Grignon, Pierson, and Neimann, 1968; Winchester, Grossman, Lim, and Danes, 1969; Brown and Kuwabara, 1970). Some of these observations are strongly indicative of the existence of new syndromes, as exemplified by the following case report.

The patient, a 16-year-old Algerian girl, suffered from severe dwarfism, moderate hepatomegaly, mental retardation, and anaemia. Bone marrow cells and circulating lymphocytes were vacuolated. $X$-ray examination did not disclose the bone dysplasia typical of the Hurler syndrome. Mucopolysacchariduria amounted to $30 \mathrm{mg} / \mathrm{l}$, with a substantial fraction behaving on chromatography as keratansulphate. The liver ultrastructure was quite unusual: lysosomes were loaded with osmiophilic lamellar materials and there was no indication of the presence of mucopolysaccharides in lysosomes (Van Hoof, 1972, 1973a; see also fig 19). $\alpha$-Galactosidase, $\beta$ glucuronidase, and $\beta$-glycerophosphatase were about three times more active than in controls; 11 other acid hydrolases were in the normal range.

It is not impossible that this girl suffered from a syndrome related to that reported by Diebold et al (1972) and Reynès et al (1973) in a patient affected by a splenic lipidosis with sea-blue histiocytes, and by a slightly excessive mucopolysacchariduria $(15.3 \mathrm{mg} / \mathrm{l})$. In both patients the lysosomes had a somewhat similar ultrastructural appearance.

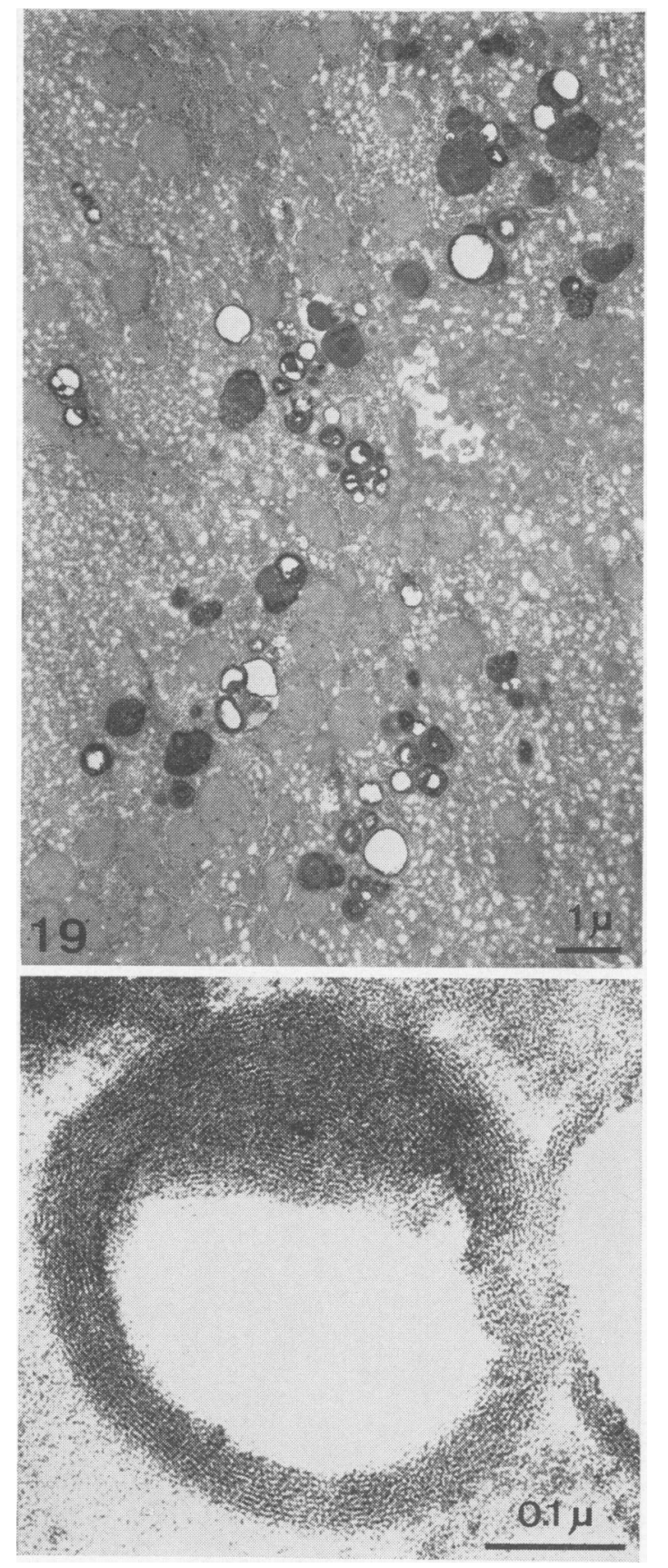

Fig 19 Unusual case with keratan sulphaturia (patient of $\mathrm{Dr}$ D. Rosenberg, Lyon). Lysosomes of liver parenchymal cells contain lamellar material (see enlargement, below). There is no indication of mucopolysaccharide storage in the various types of cells, in this liver specimen. 


\section{Frequency}

It is always difficult to estimate the real frequency of a rare disease, since most cases escape detection or, when they are detected, are not reported. On the other hand, the same unusual observation is sometimes reported by many authors.

Starting with the 527 patients compiled by Hienz (1950) in the world literature, it can be estimated that well over 1000 patients with the Hurler syndrome have been reported by now. Spranger (1972a), from these data and from his own experience, estimates the frequency of mucopolysaccharidoses with mucopolysacchariduria at about 1 case in 30000 births in Caucasians. Mucolipidoses have been more recently defined; even for that most frequently diagnosed ( $\mathrm{GM}_{1}$-gangliosidosis) fewer than 100 cases have been reported.

Table II summarizes our experience in Louvain. From 1965 to 1973 we analysed biological material from 129 patients, 74 males and 52 females, certainly suffering from a mucopolysaccharidosis or mucolipidosis. Six additional patients were referred to us whom we do not include in these statistics because their diagnosis remains uncertain. One such patient is discussed above (see fig 11).

From the table a minimal frequency for the various disorders or mucopolysaccaride metabolism can be estimated by assuming that all existing Belgian patients were referred to us from 1965 to 1973 (which is certainly not the case). Three cases of mucopolysaccharidosis with mucopolysacchariduria are diagnosed each year in Belgium (about 1 case in 45000 births) and one case with mucolipidosis. Data from other countries are certainly incomplete and biased by the fact that sending material abroad may seem justified only for patients with unusual features, so that these data cannot be used for estimation of frequency. One striking fact, however, is evident from our data: mucolipidoses and perhaps mucopolysaccharidoses are more frequent in populations from the Mediterranean basin. Five out of the seven or eight cases with mucolipidosis diagnosed in Belgium originated in Italy, Spain, or Portugal. This striking situation was also evident among the cases referred to us for diagnosis from France, Germany, and Switzerland.

\section{Conclusion}

Overwhelming evidence has been obtained that mucopolysaccharidoses and mucolipidoses are inborn lysosomal diseases. They are generalized diseases; the stored material accumulates in lysosomes, the enzymatic defects detected so far concern lysosomal or, at least, acid hydrolases. The pathogenesis of mucolipidosis type II and perhaps type III seems to be somewhat different, but there is no doubt that these pathological conditions are also inborn lysosomal diseases. Practical implications of this fact are important in relation to therapy (for a review, see de Duve, de Barsy, Poole, Trouet, Tulkens, and Van Hoof, 1974).

HOW DO THE STORED SUBSTANCES ENTER THE LYSOSOMAL SYSTEM?

Autophagy is probably responsible for engulfed glycolipid material in most cells. Heterophagy accounts for mucopolysaccharide accumulation in such tissues as liver, spleen, or kidney, which do not

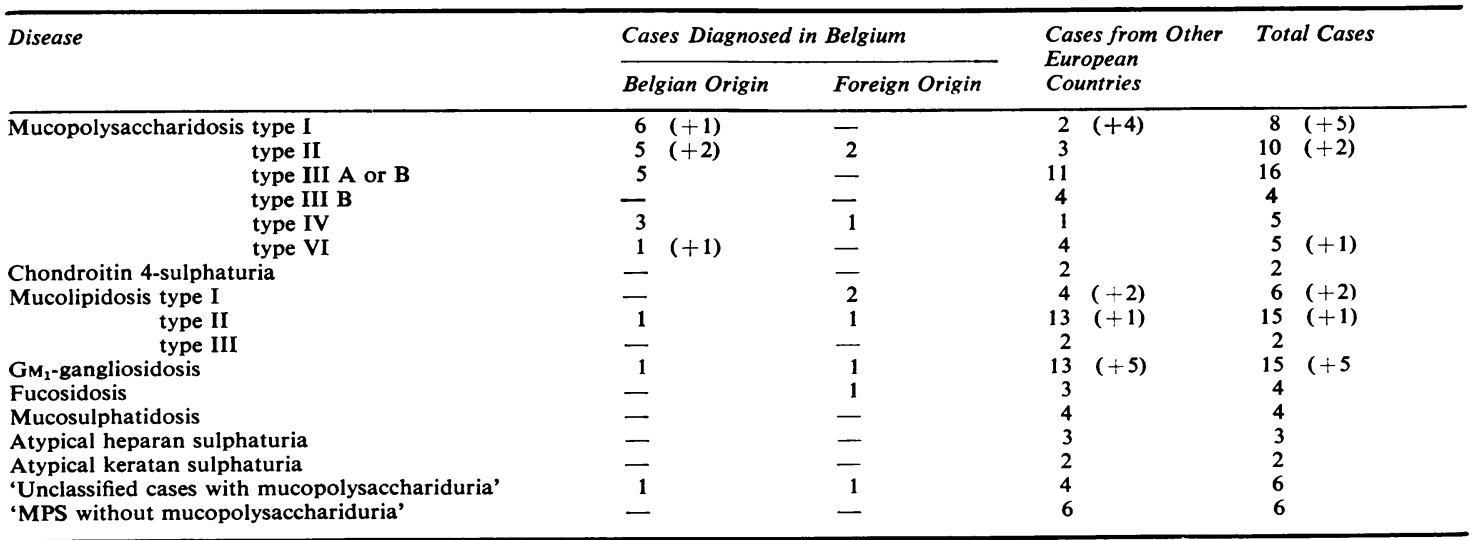

Table II Diagnosis in 129 cases of mucopolysaccharidosis or mucolipidosis studied in Louvain during 1965-19731

${ }^{1}$ Diagnosis rests on different data; some are indisputable (enzyme deficiency, typing in cultured fibroblasts, evidence of X-linked transmission), some strongly suggestive (eg, type of mucopolysaccharides excreted in urine), others only indicative (eg, clinical data). Cases where diagnosis remained tentative are indicated in parentheses. 
synthesize these substances. Conversely, in mucopolysaccharide-synthesizing cells such as fibroblasts, leucocytes, or the endothelial cells of blood vessels, crinophagy, ie, direct fusion of secretory granules with lysosomes, might be the most important mechanism by which deposits are formed. Crinophagy of glycocalyx components has also been claimed to be responsible for enlarged lysosomes in intestinal absorptive cells (Daems et al, 1973; Ginsel et al, 1973).

HOW DO NORMAL LYSOSOMES DIGEST MUCOPOLYSACCHARIDES?

Most mucopolysaccharides exist in tissues as extracellular proteoglycan complexes (for a review, see Muir, 1973). They are thus composed of a protein chain to which several glycosaminoglycan chains are attached by means of an oligosaccharide bridge. Lysosomes contain endo- and exopeptidases whose synergistic action is able to digest proteins completely (for a review, see Vaes, 1973). There are indications that the role of lysosomal proteolytic enzymes is not restricted to the lysosomal apparatus and that these hydrolases may, in some instances, be excreted from lysosomes into the extracellular spaces and release chondroitin sulphate from the cartilage matrix (Fell and Dingle, 1963; Barrett, 1966).

The digestion of the polysaccharide part of proteoglycans necessitates the action of several enzymes. Most of them are needed for the hydrolysis of osidic linkages. Glycosidases acting on all the presently known osidic linkages have been demonstrated and most are found to be lysosomal enzymes. This is the case for $\beta$-xylosidase, $\beta$-galactosidase, $\alpha$-mannosidase, and aspartyl-N-acetyl- $\beta$-glycosaminidase, which are mostly necessary for the digestion of the oligosaccharide bridges; and also for $\beta$-glucuronidase, $\alpha$-iduronidase, $\alpha$-fucosidase, $\mathrm{N}$-acetyl- $\beta$-hexosaminidase, and $\mathrm{N}$-acetyl- $\alpha$-glucosaminidase, whose conjugated action is needed to hydrolyse glycosaminoglycans (for reviews, see Van Hoof, 1972; Muir, 1973; Vaes, 1973).

In addition, the digestion of mucopolysaccharides requires the presence of a few sulphatases in the lysosomes; their exact number is uncertain, since the specificity of the different sulphatases is not yet clear. Sulphatases A and B are lysosomal, and the properties of $\mathrm{N}$-sulphatase and iduronate sulphatase suggest that these are too.

HOW DOES THE LYSOSOMAL SYSTEM REACT TO OVERLOADING?

Many cells obviously tolerate a substantial increase in the size of their lysosomes. Morphometric analysis of liver micrographs in $\mathrm{GM}_{1}$-gangliosidosis and in
Hurler and Sanfilippo disease reveal that lysosomes may increase their volume at least by a factor of 30 , and yet liver function remains practically undisturbed. It is likely that liver cells can get rid of their excess mucopolysaccharides by defaecation of the content of their lysosomes into the bile capillaries. This possibility, however, does not exist for other cells, which sooner or later cease to tolerate the lysosomal overloading.

Some experiments suggest that regulatory mechanisms exist, which decrease the rate of heterophagy, when lysosomes are distended. In cultured fibroblasts, for instance, there seems to be a limit to the relative volume that lysosomes can occupy: $25-27 \%$ of the cell volume (Van Hoof, 1972, 1973a). The same limit is found in I-cells and in rat fibroblasts cultured in the presence of antilysosome antibodies. In the latter cells, it has been shown that, while the digestion of fluorescein-labelled $\gamma$-globulin was stopped by the treatment, this protein did not accumulate in excessive amounts in the cells, indicating that capture by endocytosis had been reduced (Tulkens et al, 1970).

Another effect of lysosomal dilatation is the increase in the activity of lysosomal hydrolases. This phenomenon has been demonstrated in experimental conditions (for a review, see Lloyd, 1973) and is currently observed in practically all inborn lysosomal disorders (Hers, 1973).

The mechanism by which the accumulation of materials within lysosomes results in the cell dysfunction or death remains largely conjectural.

\section{References}

Aleu, F. P., Terry, R. D., and Zellweger, H. (1965). Electron microscropy of two cerebral biopsies in gargoylism. J. Neuropsth. exp. Neurol., 24, 304-317.

Austin, J. H. (1965). Mental retardation metachromatic leukodystrophy. In Medical Aspects of Mental Retardation, edited by C. H. Carter, pp. 768-813. Thomas, Springfield, Illinois.

Austin, J. H. (1973a). Studies in metachromatic leukodystrophy. XII. Multiple s slphatase deficiency. Arch. Neurol., 28, 258-264.

Austin, J. H. (1973b). Metachromatic leukodystrophy (sulphatide lipidosis). In Lysosomes and Storage Diseases, edited by H. G. Hers and F. Van Hoof, pp. 411-437. Academic Press, New York.

Bach, G., Eisenberg, F., Jr., Cantz, M., and Neufeld, E. F. (1973). The defect in the Hunter syndrome: deficiency of s Ilphoiduronate sulphatase. Proc. nat. Acad. Sci. (Wash.), 70, $2134-2138$.

Bach, G., Friedman, R., Weissmann, B., and Neufeld, E. F. (1972). The defect in the Hurler and Scheie syndromes: deficiency of a-L-iduronidase. Proc. nat. Acad. Sci. (Wash.), 69, 2048-2051.

Baker, H. J., Jr., Lindsey, J. R., McKhann, G. M., and Farrell, D. F. (1971). Ne:ıronal $\mathrm{GM}_{1}$-gangliosidosis in a siamese cat with $\beta$-galactosidase deficiency. Science, 174, 838-839.

Barrett, A. J. (1966). Chondromucoprotein-degrading enzymes. Nature (Lond.), 211, 1188-1189.

Barton, R. W., and Ne ifeld, E. F. (1972). A distinct biochemical deficit in the Marntea'Ix-Lamy syndrome $(m \mathrm{c}>n-1 v s a c c h a r i-$ dosis VI). J. Pediat., 80, 114-116.

Beaudet, A. L., DiFerrante, N., Nichols, B., and Ferr', r. D. (1972). $\beta$-Gluc'ironidase deficiency: altered enzyme $s$ 'strate recognition. Amer. J. hum. Geret., 24, 25a.

Bischoff, A., and Ulrich, J. (1967). Amaurotische Idinti- in Verbindung 
mit metachromatischer Leukodystrophie: Ubergangsform oder Kombination? Elektronenmikroskopische und histochemische Befunde. Acta neuropath. (Berl.), 8, 292-308.

Booth, C. W., and Nadler, H. L. (1973). Plasma infusion in an infant

14 with Hurler's syndrome. J. Pediat., 82, 273-278.

Borri, P. F., Hooghwinkel, G. J. M., and Edgar, G. W. F. (1966). Brain ganglioside pattern in three forms of amaurotic idiocy and in gargoylism. J. Neurochem., 13, 1249-1256.

Borrone, C., Gatti, R., Trias, X., and Durand, P. (1974). Fucosidosis: clinical, biochemical, immunologic and genetic studies in two new cases. J. Pediat., 84, 727-734.

Bowers, W. E., and de Duve, C. (1967). Lysosomes in lymphoid tissue. II. Intracellular distribution of acid hydrolases. J. Cell Biol., 32, 339-348.

Brante, G. (1952). Gargoylism: a mucopolysaccharidosis. Scand. J. clin. Lab. Invest., 4, 43-46.

Brown, S. I., and Kuwabara, T. (1970). Peripheral corneal opacification and skeletal deformities. Arch. Ophthal., 83, 667-677.

Campailla, E., and Martinelli, B. (1969). Osteocondrodistrofia dell'accrescimento con mucopolisaccariduria. Boll. Soc. ital. Biol. sper., 45, 1145-1146.

Carroll, M., Dance, N., Masson, P. K., Robinson, D., and Winchester, B. G. (1972). Human mannosidosis: the enzymic defect. Biochem, biophys. Res. Commun., 49, 579-583.

Clausen, J., Dyggve, H. V., Melchior, J. C., and Christensen Lou, H. O. (1967). Chemical studies in gargoylism. Arch. Dis. Childh., 42, 62-69.

Conchie, J., and Hay, A. J. (1963). Mammalian glycosidases. 4. The intracellular localization of $\beta$-galactosidase, a-mannosidase, $\beta$ - $\mathrm{N}$-acetylglucosaminidase and $\alpha$ - $\mathrm{L}$-fucosidase in mammalian tissues. Biochem. J., 87, 354-361.

Coppa, G. V., Singh, J., Nichols, B. L., and Di Ferrante, N. (1973), Urinary excretion of disulfated disaccharides in Hunter syndrome. Correction by infusion of a serum fraction. Anal. Letters, 6, 225-233.

Crocker, A. C. (1972). Plasma infusion therapy for Hurler's syndrome. Pediatrics, 50, 683-685.

Daems, W. T. (1962). Mouse liver lysosomes and storage: a morphological and histochemical study. Thesis, Luctor et Emergo, Leiden, $89 \mathrm{pp}$.

Daems, V. T., van Gemund, J. J., Vio, P. M. A., Willighagen, R. G. J., and Den Tandt, W. R. (1973). The use of intestinal suctionbiopsy material for the study of lysosomal storage diseases. In Lysosomes and Storage Diseases, edited by H. G. Hers and F. Van Hoof, pp. 575-598. Academic Press, New York.

Danes, B. S., and Bearn, A. G. (1966). Hurler's syndrome: a genetic study in cell culture. J. exp. Med., 123, 1-16.

Danes, B. S., Degnan, M., Salk, L., and Flynn, F. J. (1972). Treatment of Hurler syndrome. (Letter) Lancet, 2, 883

Dawson, G. (1972). Glycosphingolipid abnormalities in liver from patients with glycosphingolipid and mucopolysaccharide storage diseases. In Sphingolipids, Sphingolipidoses and Allied Disorders, edited by B. W. Volk and S. M. Aronson, pp. 395413. Plenum Press, New York and London.

Dawson, G., Matalon, R., and Dorfman, A. (1972). Glycosphingolipids in cultured human skin fibroblasts. II. Characterization and metabolism in fibroblasts from patients with inborn errors of glycosphingolipid and mucopolysaccharide metabolism. J. biol. Chem., 247, 5951-5958.

Dawson, G., and Spranger, J. W. (1971). Fucosidosis: a glycosphingolipidosis. New Engl. J. Med., 285, 122.

Dean, M. F., Muir, H., and Benson, P. F. (1973). Mobilization of glycosaminoglycans by plasma infusion in mucopolysaccharidosis type III: two types of response. Nature [new Biol.], 243, 143-146.

de Duve, C., de Barsy, T., Poole, B., Trouet, A., Tulkens, P., and Van Hoof, F. (1974). Lysosomotropic agents. Biochem. Pharmacol., 23, 2495-2531.

de Duve, C., Pressman, B. C., Gianetto, R., Wattiaux, R., and Appelmans, F. (1955). Tissue fractionation studies. VI. Intracellular distribution patterns of enzymes in rat liver tissue. Biochem. J., 60, 604-617.

de Duve, C., and Wattiaux, R. (1966). Functions of lysosomes. Ann. Rev. Physiol., 28, 435-492.

Dekaban, A. S., Holden, K. R., and Constantopoulos, G. (1972). Effects of fresh plasma or whole blood transfusions on patients with various types of mucopolysaccharidosis. Pediatrics, 50, 688-692.

De Mars, R., and Leroy, J. G. (1967). The remarkable cells cultured from a human with Hurler's syndrome: an approach to visua selection for in vitro genetic studies. In Vitro, 2, 107-118.

de Montis, G., Garnier, P., Thomassin, N., Job, J. C., and Rossier, A. (1972). La mucolipidose type II (maladie des cellules à inclusions): étude d'un cas et revue de la littérature. Ann. Pćdiat. 19, 369-379.

Derry, D. M., Fawcett, J. S., Andermann, F., and Wolfe, L. S. (1968). Late infantile systemic lipidosis: major monosialogangliosidosis; delineation of two types. Neurology (Minneap.), 18, 340-348.

Desnick, R. J., Bernlohr, R. W., and Krivit, W. (Eds). (1973). Enzyme Therapy in Genetic Diseases. Birth Defects (Original Articles Series, 9). The National Foundation, New York.

Diebold, J., Bernadou, A., Kalifat, R., Ganter, P., and Reynès, M. (1972). Lipidose splénique avec histiocytes 'bleu marine' par accumulation de céroìdes. Nouv. Presse méd., 1, 1983-1988.

Di Ferrante, N., Nichols, B. L., Donnelly, P. V., Neri, G., Hrgovcic, R., and Berglund, R. K. (1971). Induced degradation of glycosaminoglycans in Hurler's and Hunter's syndromes by plasma infusion. Proc. nat. Acad. Sci. (Wash.), 68, 303-307.

Dingle, J. T., and Fell, H. B. (Eds.) (1969). Lysosomes in Biology and Pathology, vols. 1 and 2. North-Holland, Amsterdam and London.

Dorfman, A., and Lorincz, A. E. (1957). Occurrence of urinary acid mucopolysaccharides in the Hurler syndrome. Proc. nat. Acad. Sci. (Wash.), 43, 443-446.

Dorfman, A., and Matalon, R. (1972). The mucopolysaccharidoses. In The Metabolic Basis of Inherited Disease, edited by J. B. Stanbury, J. B. Wyngaarden, and D. S. Fredrickson, 3rd ed., pp. 1218-1272. McGraw-Hill, New York.

Durand, P., Borrone, C., and Della Cella, G. (1966). A new mucopolysaccharide lipid-storage disease? (Letter) Lancet, 2, 1313-1314.

Durand, P., Borrone, C., and Della Cella, G. (1969a). Fucosidosis. J. Pediat., 75, 665-674.

Durand, P., Borrone, C., Della Cella, G., and Philippart, M. (1968). Fucosidosis. Lancet, 2, 1198.

Durand, P., Philippart, M., Borrone, C., Della Cella, G., and Bugiani, O. (1967). Una nuova malattia da accumulo di glicolipidi. Minerva pediat., 19, 2187-2196.

Durand, P., Philippart, M., Borrone, C., and Della Cella, G. (1969b). Fucosidosis. In Enzymopenic Anaemias, Lysosomes and Other Papers: Proceedings of the Sixth Symposium of the Society for the Study of Inborm Errors of Metabolism, edited by J. D. Allan, K. S. Holt, J. T. Ireland, and R. J. Pollitt, pp. 90-93. Livingstone, Edinburgh.

Ellis, R. W. B., Sheldon, W., and Capon, N. B. (1936). Gargoylism (chondro-osteo-dystrophy, corneal opacities, hepatosplenomegaly, and mental deficiency). Quart. J. Med., 5, 119-139.

Epinette, W. W., Norins, A. L., Drew, A. L., Zeman, W., and Patel, V. (1973). Angiokeratoma corporis diffusum with $a$-L-fucosidase deficiency. Arch. Dermat., 107, 754-757.

Erickson, R. P., Sandman, R., Robertson, W. van B., and Epstein, C. J. (1972). Inefficacy of fresh frozen plasma therapy of mucopolysaccharidosis. II. Pediatrics, 50, 693-701.

Fell, H. B., and Dingle, J. T. (1963). Studies on the mode of action of excess of vitamin A. 6 . Lysosomal protease and the degradation of cartilage matrix. Biochem. J., 87, 403-408.

Fratantoni, J. C., Hall, C. W., and Neufeld, E. F. (1968a). The defect in Hurler's and Hunter's syndromes: faulty degradation of mucopolysaccharide. Proc. Nat. Acad. Sci. (Wash.), 60, 699706.

Fratantoni, J. C., Hall, C. W., and Neufeld, E. F. (1968b). Hurler and Hunter syndromes: mutual correction of the defect in cultured fibroblasts. Science, 162, 570-572.

Fratantoni, J. C., Neufeld, E. F., Uhlendorf, B. W., and Jacobson, C. B. (1969). Intrauterine diagnosis of the Hurler and Hunter syndromes. New Engl. J. Med., 280, 686-688.

Freitag, F., Blümcke, S., and Spranger, J. (1971a). Hepatic ultrastructure in mucolipidosis I (lipomucopolysaccharidosis) Virchows Arch. Abt. B Zellpath., 7, 189-204.

Freitag, F., Küchemann, K., and Blümcke, S. (1971b). Hepatic ultrastructure in fucosidosis. Virchows Arch. Abt. B Zellpath., 7, 99-113.

Freitag, F., Küchemann, K., Schuster, W., and Spranger, J. (1971c). Hepatic ultrastructure in chondroitin-4-sulfate mucopolysaccharidosis. Virchows Arch Abt. B Zellpath., 8, 1-15.

Gatti, R., Borrone, C., Trias, X., and Durand, P. (1973). Genetic heterogeneity in fucosidosis. (Letter) Lancet, 2, 1024.

Gilbert, E. F., Dawson, G., Zu Rheim, G. M., Opitz, J. M., and Spranger, J. W. (1973). I-Cell Disease, mucolipidosi II. 
Pathological, histochemical, ultrastructural, and biochemical observations in four cases. $Z$. Kinderheilk, 114, 259-292.

Ginsel, L. A., Daems, W. T., Emeis, J. J., Vio, P. M. A., and van Gemund, J. J. (1973). Fine structure and silver-staining patterns of lysosome-like bodies in absorptive cells of the small intestine in normal children and children with a lysosomal storage disease. Virchows Arch. Abt. B Zellpath., 13, 119-144.

Gollance, R. B., and D'Amico, R. A. (1967). Atypical mucopolysaccharidosis and successful keratoplasty. Amer. J. Ophthal., 64, 707-716.

Gonatas, N. K., and Gonatas, J. (1965). Ultrastructural and biochemical observations on a case of systemic late infantile lipidosis and its relationship to Tay-Sachs disease and gargoylism. J. Neuropath. exp. Neurol., 24, 318-340.

Hall, C. W., Cantz, M., and Neufeld, E. F. (1973). A $\beta$-glucuronidase deficiency mucopolysaccharidosis: studies in cultured fibroblasts. Arch. Biochem., 155, 32-38.

Hanai, J., Leroy, J., and O'Brien, J. S. (1971). Ultrastructure of cultured fibroblasts in I-Cell disease. Amer. J. Dis. Child., 122, 34-38.

Handa, S., and Yamakawa, T. (1971). Biochemical studies in cat and human gangliosidosis. J. Neurochem., 18, 1275-1280.

Hers, H. G. (1961). Recent developments in the biochemistry of glycogen storage disease and of fructose intolerance. Chem. Weekblad, 57, 437-440.

Hers, H. G. (1963). $a$-Glucosidase deficiency in generalized glycogenstorage disease (Pompe's disease). Biochem. J., 86, 11-16.

Hers, H. G. (1965). Inborn lysosomal diseases. Gastroenterology, 48, 625-633.

Hers, H. G. (1973). The concept of inborn lysosomal disease. In Lysosomes and Storage Diseases, edited by H. G. Hers and F. Van Hoof, pp. 147-171. Academic Press, New York.

Hers, H. G., and de Barsy, T. (1973). Type II glycogenosis (acid maltase deficiency). In Lysosomes and Storage Diseases, edited by H. G. Hers and F. Van Hoof, pp. 197-216. Academic Press, New York.

Hers, H. G., and Van Hoof, F. (1968). Glycogen storage diseases: type II and type VI glycogenosis. In Carbohydrate Metabolism and Its Disorders, edited by F. Dickens, P. J. Randle, and W. J. Whelan, vol. II, pp. 151-168. Academic Press, New York and London.

Hers, H. G., and Van Hoof, F. (1969). Genetic abnormalities of lysosomes. In Lysosomes in Biology and Pathology, edited by J. T. Dingle and H. B. Fell, vol. II, pp. 19-40. North-Holland, Amsterdam.

Hers, H. G., and Van Hoof, F. (1970). The genetic pathology of lysosomes. In Progress in Liver Disease, edited by H. Popper and F. Schaffner, vol. III, pp. 185-205. Grune and Stratton, New York and London.

Hickman, S., and Neufeld, E. F. (1972). A hypothesis for I-cell disease: defective hydrolases that do not enter lysosomes. Biochem. Biophys. Res. Commun., 49, 992-999.

Hienz, H. (1960). Die Pfaundler-Hurlersche Krankheit. Ergebn. allg. Path. path. Anat., 40, 1-33.

Ho, M. W., and O'Brien, J. S. (1969). Hurler's syndrome: deficiency of a specific beta-galactosidase isoenzyme. Science, 165, 611-613.

Hocking, J. D., Jolly, R. D., and Batt, R. D. (1972). Deficiency of a-mannosidase in Angus cattle: an inherited lysosomal storage disease. Biochem. J., 128, 69-78.

Hof, L., Matalon, R., and Dorfman, A. (1971). Gangliosides in human skin fibroblasts and their enrichment in the 'Hurler variant' and Krabbe's disease. Hoppe-Seyler's Z. Physiol. Chem., 352, 1329-1337.

Hunter, C. (1917). A rare disease in two brothers. Proc. roy. Soc. Med., 10 (Sect. Dis. Child.), 104-116.

Hurler, G. (1920). Ueber einen Typ multipler Abartungen, vorwiegend am Skelettsystem. $Z$. Kinderheilk., 24, 220-234.

Jolly, R. D. (1970). Diagnosis and control of pseudolipidosis of Angus calves. N.Z. vet. J., 18, 228-229.

Jolly, R. D. (1971). The pathology of the central nervous system in pseudolipidosis of Angus calves. J. Path., 103, 113-121.

Jolly, R. D., and Blakemore, W. F. (1973). Inherited lysosoma storage diseases: an essay in comparative medicine. Vet. Rec., 92, 391-400.

Kaback, M. M., Sloan, H. R., Sonneborn, M., Herndon, R. M., and

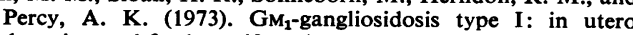
detection and fetal manifestations. J. Pediat., 82, 1037-1041.

Kaplan, D., McKusick, V., Trebach, S., and Lazarus, R. (1968) Keratosulfate-chondroitin sulfate peptide from normal urine and from urine of patients with Morquio syndrome (mucopoly- saccharidosis IV). J. Lab. clin. Med., 71, 48-55.

Kenyon, K. R., Topping, T. M., Green, W. R., and Maumenee, A. E. (1972). Ocular pathology of the Maroteaux-Lamy syndrome (systemic mucopolysaccharidosis type VI): histologic and ultrastructural report of two cases. Amer. J. Ophthal., 73, 718741.

Kint, J. A., Dacremont, G., Carton, D., Hooft, C., and Loeb, H. (1971). Abnormal distribution patterns of lysosomal isoenzymes in mucopolysaccharidosis. New Engl. J. Med., 285, 1537-1538.

Kint, J. A., Dacremont, G., Carton, D., Orye, E., and Hooft, C. (1973). Mucopolysaccharidosis: secondarily induced abnormal distribution of lysosomal isoenzymes. Science, 181, 352-354.

Knudson, A. G., Jr., Di Ferrante, N., and Curtis, J. E. (1971). Effect of leukocyte transfusion in a child with type II mucopolysaccharidosis. Proc. nat. Acad. Sci. (Wash.), 68, 1738-1741.

Kousseff, B. G., Beratis, N. G., Danesino, C. and Hirschhorn, K. (1973). Genetic heterogeneity in fucosidosis. (Letter) Lancet, 2, 1387-1388

Kresse, H. (1973). Mucopolysaccharidosis III A (Sanfilippo A disease): deficiency of a heparin sulfamidase in skin fibroblasts and leucocytes. Biochem. biophys. Res. Commun., 54, 1111-1118.

Kresse, H., and Neufeld, E. F. (1972). The Sanfilippo A corrective factor: purification and mode of action. J. biol. Chem., 247, 2164-2170.

Kresse, H., Wiesmann, U., Cantz, M., Hall, C. W., and Neufeld, E. F. (1971). Biochemical heterogeneity of the Sanfilippo syndrome: preliminary characterization of two deficient factors. Biochem. biophys. Res. Commun., 42, 892-898.

Lagunoff, D., Nicol, D. M., and Pritzl, P. (1973). Uptake of $\beta$ glucuronidase by deficient human fibroblasts. Lab. Invest., 29 , $449-453$

Landing, B. H., Silverman, F. N., Craig, J. M., Jacoby, M. D., Lahey, M. E., and Chadwick, D. L. (1964). Familial neuroviscera lipidosis. Amer. J. Dis. Child., 108, 503-522.

Leaback, D. H. (1970). The metabolic hydrolases of hexosaminide linkages. In Metabolic Conjugation and Metabolic Hydrolysis, by W. H. Fishman, vol. II, pp. 443-517. Academic Press, New York.

Ledeen, R. (1966). The chemistry of gangliosides: a review. J. Amer. Oil Chem. Soc., 43, 57-66.

Ledeen, R., Salsman, K., Gonatas, J., and Taghavy, A. (1965), Structure comparison of the major monosialogangliosides from brains of normal human, gargoylism, and late infantile systemic lipidosis. Part I. J. Neuropath. exp. Neurol., 24, 341-351.

Leroy, J. G., and Crocker, A. C. (1966). Clinical definition of the Hurler-Hunter phenotypes. Amer. J. Dis. Child., 112, 518-530.

Leroy, J. G., and Crocker, A. C. (1967). Studies on the genetics of the Hurler-Hunter syndrome. In Inborn Disorders of Sphingolipid Metabolism, edited by S. M. Aronson and B. W. Volk, pp. 455-473. Pergamon Press, Oxford.

Leroy, J. G., and DeMars, R. I. (1967). Mutant enzymatic and cytological phenotypes in cultured human fibroblasts. Science, 157, 804-806.

Leroy, J. G., Ho, M. W., MacBrinn, M. C., Zielke, K., Jacob, J., and O'Brien, J. S. (1972). I-cell disease: biochemical studies. Pediat. Res., 6, 752-757.

Leroy, J. G., and Spranger, J. W. (1970). I-Cell disease. New Engl. J. Med., 283, 598-599.

Leroy, J. G., Spranger, J. W., Feingold, M., Opitz, J. M., and Crocker, A. C. (1971). I-cell disease: a clinical picture. J. Pediat., 79, 360-365.

Leroy, J. G., and van Elsen, A. F. (1973). I-Cell disease (mucolipidosis type II): serum hydrolases in obligate heterozygotes. Humangenetik, 20, 119-123.

Lightbody, J., Wiesmann, U., Hadorn, B., and Herschkowitz, N. (1971). I-Cell disease: multiple lysosomal-enzyme defect. (Letter) Lancet, 1, 451.

Lie, S. O., McKusick, V. A., and Neufeld, E. F. (1972). Simulation of genetic mucopolysaccharidoses in normal human fibroblasts by alteration of pH of the medium. Proc. nat. Acad. Sci. (Wash.), 69, 2361-2363.

Lie, S. O., and Schofield, B. H. (1973). Inactivation of lysosomal function in normal cultured human fibroblasts by chloroquine. Biochem. Pharmacol., 22, 3109-3114.

Lie, S. O., Schofield, B. H., Taylor, H. A., Jr., and Doty, S. B. (1973). Structure and function of the lysosomes of human fibroblasts in culture: dependence on medium pH. Pediat. Res., 7, 13-19.

Lindahl, U., and Axelsson, O. (1971). Identification of iduronic acid 
as the major sulfated uronic acid of heparin. J. biol. Chem., 246, 74-82.

Linker, A., Evans, L. R., and Langer, L. O. (1970). Morquio's disease and mucopolysaccharide excretion. J. Pediat., 77, 1039-1047.

Lloyd, J. B. (1973). Experimental support for the concept of lysosomal storage disease. In Lysosomes and Storage Diseases, edited by H. G. Hers and F. Van Hoof, pp. 173-195. Academic Press, New York.

Loeb, H., Cremer, N., and Denolin-Reubens, R. (1969a). Etude clinique des mucopolysaccharidoses. XXIIe Congrès de l'Association des Pédiatres de Langue Française, Strasbourg Rapports, vol. 3, pp. 139-180.

Loeb, H., Tondeur, M., Jonniaux, G., Mockel-Pohl, S., and VamosHurwitz, E. (1969b). Biochemical and ultrastructural studies in a case of mucopolysaccharidosis 'F' (fucosidosis). Helv. paediat. Acta, 24, 519-537.

Loeb, H., Tondeur, M., Résibois, A., Jonniaux, G., and Van Hoof, F. (1969c). Biochemical and ultrastructural studies in a case of mucopolysaccharidosis ' $F$ '. In Enzymopenic Anaemias, Lysosomes and Other Papers: Proceedings of the Sixth Symposium of the Society for the Study of Inborn Errors of Metabolism, edited by J. D. Allan, K. S. Holt, J. T. Ireland, and R. J. Pollitt, pp. 94-95. Livingstone, London.

Loeb, H., Tondeur, M., Toppet, M., and Cremer, N. (1969d). Clinical biochemical and ultrastructural studies of an atypical form of mucopolysaccharidosis. Acta paediat. scand., 58, 220-228.

Lowden, J. A., Cutz, E., Conen, P. E., Rudd, N., and Doran, T. A. (1973). Prenatal diagnosis of $\mathrm{GM}_{1}$-gangliosidosis. New Engl. J. Med., 288, 225-228.

Lyon, G., Hors-Cayla, M. C., Jonsson, V., and Maroteaux, P. (1973), Aspects ultrastructuraux et signification biochimique des granulations métachromatiques et autres inclusions dans les fibroblastes en culture provenant de lipidoses et de mucopolysaccharidoses. J. neurol. Sci., 19, 235-253.

MacBrinn, M. C., Okada, S., Ho, M. W., Hu, C. C., and O'Brien, J. S. (1969). Generalized gangliosidosis: impaired cleavage of galactose from a mucopolysaccharide and a glycoprotein. Science, 163, 946-947.

McKusick, V. A. (1973). Analytic review: phenotypic diversity of human diseases resulting from allelic series. Amer. J. hum. Genet., 25, 446-456.

McKusick, V. A., Howell, R. R., Hussels, I. E., Neufeld, E. F., and Stevenson, R. E. (1972). Allelism, non-allelism, and genetic compounds among the mucopolysaccharidoses. Lancet, 1 , 993-996.

McKusick, V. A., Kaplan, D., Wise, D., Hanley, W. B., Suddarth, S. B., Sevick, M. E., and Maumanee, A. E. (1965). The genetic mucopolysaccharidoses. Medicine (Baltimore), 44, 445-483.

Malmström, A., and Fransson, L. A. (1971). Structure of pig skin dermatan sulfate. 2. Demonstration of sulfated iduronic acid residues. Europ. J. Biochem., 18, 431-435.

Marchal, C., Grignon, G., Humbel, R., Vidailhet, M., Fall, M., Grignon, M., Pierson, M., and Neimann, N. (1968). Mucopolysaccharidose sans mucopolysaccharidurie. Ann. pediat., 15, 605-611.

Maroteaux, P. (1970). Différenciation biochimique des maladies de Hurler et de Hunter par fractionnement de l'héparitine sulfate. Rev. europ. Etud. clin. Biol., 15, 203-205.

Maroteaux, P. (1973). Un nouveau type de mucopolysaccharidose avec athétose et élimination urinaire de kératan-sulfate. Nouv. Presse Méd., 2, 975-979.

Maroteaux, P., Hors-Cayla, M. C., and Pont, J. (1970). La mucolipidose de type II. Presse méd., 78, 179-181.

Maroteaux, P., and Lamy, M. (1965). Hurler's disease, Morquio's disease, and related mucopolysaccharidoses. J. Pediat., 67, 312-323.

Maroteaux, P., and Lamy, M. (1966). La pseudo-polydystrophie de Hurler. Presse mé.l., 74, 2889-2892.

Maroteaux, P., Lévêque, B., Marie, J., and Lamy, M. (1963). Une nouvelle dysostose avec élimination urinaire de chondroîtinesulfate B. Presse méd., 71, 1849-1852.

Matalon, R., Cifonelli, J. A., and Dorfman, A. (1971). L-iduronidase in cultured human fibroblasts and liver. Biochem. biophys. Res. Commun., 42, 340-345.

Matalon, R., Cifonelli, J. A., Zellweger, H., and Dorfman, A. (1968). Lipid abnormalities in a variant of the Hurler syndrome. Proc. nat. Acad. Sci. (Wash.), 59, 1097-1102.

Matalon, R., and Dorfman, A. (1966). Hurler's syndrome: biosynthesis of acid mucopolysaccharides in tissue culture. Proc. nat. Acad. Sci. (Wash)., 56, 1310-1316.
Matalon, R., and Dorfman, A. (1972). Hurler's syndrome, an a-Liduronidase deficiency. Biochem. biophys. Res. Commun., 47, 959-964.

Matalon, R., Dorfman, A., and Nadler, H. L. (1972). A chemical method for the antenatal diagnosis of mucopolysaccharidoses. Lancet, 1, 798-799.

Matalon, R., Dorfman, A., Nadler, H. L., and Jacobson, C. B. (1970). A chemical method for the antenatal diagnosis of mucopolysaccharidoses. Lancet, 1, 83-84.

Matsuda, I., Arashima, S., Anakura, M., Ege, A., and Hayata, I. (1973). Fucosidosis. Tohoku J. exp. Med., 109, 41-48.

Maynard, J. A., Cooper, R. R., and Ponseti, I. V. (1973). Morquio's disease (mucopolysaccharidosis type IV): ultrastructure of epiphyseal plates. Lab. Invest., 28, 194-205.

Melhem, R., Dorst, J. P., Scott, C. I., Jr., and McKusick, V. A. (1973) Roentgen findings in mucolipidosis III (pseudo-Hurler polydystrophy). Radiology, 106, 153-160.

Meyer, K., Grumbach, M. M., Linker, A., and Hoffman, P. (1958). Excretion of sulfated mucopolysaccharides in gargoylism (Hurler' syndrome). Proc. Soc. exp. Biol. (N.Y.), 97, 275-279.

Meyer, K., Hoffman, P., Linker, A., Grumbach, M. M., and Sampson, P. (1959). Sulfated mucopolysaccharides of urine and organes in gargoylism (Hurler's syndrome). II. Additional studies. Proc. Soc. exp. Biol. (N.Y.), 102, 587-590.

Morquio, L. (1929). Sur une forme de dystrophie osseuse familiale. Arch. Méd. Enf., 32, 129-140.

Moser, H. W., Sugita, M., Harbison, M. D., and Williams, M. (1972). Liver glycolipids, steroid sulfates and steroid sulfatases in a form of metachromatic leukodystrophy associated with multiple sulfatase deficiencies. In Sphingolipids, Sphingolipidoses and Allied Disorders (Advances in Experimental Medicine and Biology, vol. 19), edited by B. W. Volk and S. M. Aronson, pp. 429-450. Plenum Press, New York and London.

Muir, H. (1973). Structure and enzymic degradation of mucopolysaccharides. In Lysosomes and Storage Diseases, edited by H. G. Hers and F. Van Hoof, pp. 79-104. Academic Press, New York.

Murphy, J. V., Wolfe, H. J., Balazs, E. A., and Moser, H. W. (1971). A patient with deficiency of arylsulfatases A, B, C and steroid sulfatase, associated with storage of sulfatide, cholesterol sulfate and glycosaminoglycans. In Lipid Storage Diseases: Enzymatic Defects and Clinical Implications, edited by J. Bernsohn and H. J. Grossman, pp. 67-110. Academic Press, New York.

Neufeld, E. F. (1973). Genetic errors of mucopolysaccharide metabolism. In Proceedings of the 9th International Congress of the Federation of European Biochemical Societies, Abstract Book, p. 422.

Neufeld, E. F., and Cantz, M. (1973). The mucopolysaccharidoses studied in cell culture. In Lysosomes and Storage Diseases, edited by H. G. Hers and F. Van Hoof, pp. 261-275. Academic Press, New York.

$\mathrm{Njå,} \mathrm{A.} \mathrm{(1946).} \mathrm{A} \mathrm{sex-linked} \mathrm{type} \mathrm{of} \mathrm{gargoylism.} \mathrm{Acta} \mathrm{paediat.} \mathrm{(Upp-}$ sala) 33, 267-286.

Nordén, N. E., Eriksson, Ö. Hultberg, B., and Öckerman, P. A. (1973a). Gel chromatographic distribution of urinary carbohydrate compounds. Clin. chim. Acta., 44, 95-100.

Nordén, N., Öckerman, P. A., and Szabó, L. (1973b). Urinary mannose in mannosidosis. J. Pediat., 82, 686-688.

Novikoff, A. B. (1963). Lysosomes in the physiology and pathology of cells: contributions of staining methods. In Lysosomes (Ciba Foundation Symposium), edited by A. V. S. de Reuck and M. P. Cameron, pp. 36-77. Churchill, London.

Novikoff, A. B. (1973). Lysosomes: a personal account. In Lysosomes and Storage Diseases, edited by H. G. Hers and F. Van Hoof, pp. 1-41. Academic Press, New York.

O'Brien, J. S. (1972). Sanfilippo syndrome: profound deficiency of $a$-acetylglucosaminidase activity in organs and skin fibroblasts from type-B patients. Proc. nat. Acad. Sci. (Wash.), 69, 17201722 .

O'Brien, J. S., Stern, M. B., Landing, B. H., O'Brien, J. K., and Donnell, G. N. (1965). Generalized gangliosidosis. Amer. J. Dis. Child., 109, 338-346.

Ockerman, P. A. (1967). A generalized storage disorder resembling Hurler's syndrome. Lancet, 2, 239-241.

Öckerman, P. A. (1969). Mannosidosis: isolation of oligosaccharide storage material from brain. J. Pediat., 75, 360-365.

Öckerman, P. A. (1970). Letter to the Editor. J. Pediat., 77, 168-169.

Ockerman, P. A. (1973). Mannosidosis. In Lysosomes and Storage 
Diseases, edited by H. G. Hers and F. Van Hoof, pp. 291-304. Academic Press, New York.

Öckerman, P. A., Norden, N. E., and Szabo, L. (1972). Problems in the chemical diagnosis of glycoprotein storage diseases. In Glycolipids, Glycoproteins, and Mucopolysaccharides of the Nervous System (Advances in Experimental Medicine and Biology, vol. 25), edited by V. Zambotti, G. Tettamanti, and M. Arrigoni, pp. 281-291. Plenum Press, New York and London.

Okada, S., and O'Brien, J. S. (1968). Generalized gangliosidosis: beta-galactosidase deficiency. Science, 160, 1002-1004.

Okada, S., and O'Brien, J. S. (1969). Deficiency of ganglioside $\mathbf{G M}_{\mathbf{1}^{-}}$ galactosidase activity in generalized gangliosidosis (Abstr.). J. Neuropath. exp. Neurol., 28, 170.

Ormos, J., Monus, Z., Szabo, L., and Csapo, Z. (1971). Die Bedeutung der elektronenmikroskopischen Untersuchung der Leberbiopsie bei der Beurteilung der verschiedenen Mucopolysaccharidosen. Verh. dtsch. ges. path., 55, 399-405.

Panizon, F., Sartorelli, C., and Perona, G. (1968). La malattia di Morquio e la disostosi spondilo-metafisaria. Acta paediat. lat., 21, 552-584.

Patel, V., Watanabe, I., and Zeman, W. (1972). Deficiency of $a-\mathrm{L}$ fucosidase. Science, 176, 426-427.

Philippart, M. (1966). Le gargoylisme. Rein et Foie, 9, 245-249.

Philippart, M. (1969). Étude biochimique des sphingolipidoses et des mucopolysaccharidoses. XXIIe Congrès l'Association de Pédiatres de Langue Française, Strasbourg. Rapports, 3, pp. 5-41.

Philippart, M. (1972). Glycolipid, mucopolysaccharide and carbohydrate distribution in tissues, plasma and urine from glycolipidoses and other disorders. Complex nature of the accumulated substances. In Glycolipids, Glycoproteins and Mucopolysaccharides of the Nervous System (Advances in Experimental Medicine and Biology, vol. 25), edited by V. Zambotti, G. Tettamanti, and M. Arrigoni, pp. 231-254. Plenum Press, New York and London.

Philippart, M., and Sugarman, G. I. (1969). Chondroitin-4-sulphate mucopolysaccharidosis: a new variant of Hurler's syndrome. Lancet, 2, 854.

Quigley, H. A., and Goldberg, M. F. (1971). Conjunctival ultrastructure in mucolipidosis III (pseudo-Hurler polydystrophy). Invest. Ophthal., 10, 568-580.

Rampini, S., Isler, W., Baerlocher, K., Bischoff, A., Ulrich, J., and Plüss, H. J. (1970). Die Kombination von metachromatischer Leukodystrophie und Mukopolysaccharidose als selbständiges Krankheitsbild (Mukosulfatidose). Helv. paediat. Acta, 25, 436-461.

Rapola, J. (1972). Personal communication.

Résibois, A., Tondeur, M., Mockel, S., and Dustin, P. (1970). Lysosomes and Storage diseases. Int. Rev. exp. Path., 9, 93-149.

Reynès, M., Kalifat, R., and Diebold, J. (1973). Etude ultrastructurale des histiocytes bleu marine dans une lipidose splénique idiopathique avec surcharge en céroïdes. Virchows Arch. path. Anat., 360, 349-358.

Roy, A. B. (1958). Comparative studies on the liver sulphatases. Biochem. J., 68, 519-528.

Sacrez, R., Juif, J. G., Gigonnet, J. M., and Gruner, J. E. (1967) La maladie de Landing ou idiotie amaurotique infantile, précoce avec gangliosidose généralisée de type $\mathrm{GM}_{1}$. Pédiatrie, 22, 143-162.

Sanfilippo, S. J., Podosin, R., Langer, L., and Good, R. A. (1963) Mental retardation associated with acid mucopolysacchariduria (heparitin sulfate type). J. Pediat., 63, 837-838.

Scheie, H. G., Hambrick, G. W., Jr., and Barness, L. A. (1962). A newly recognized forme fruste of Hurler's disease (gargoylism). Amer. J. Ophthal., 53, 753-769.

Schimke, R. N., Horton, W. A., and King, C. R. (1971). Chondroitin6-sulphaturia, defective cellular immunity, and nephrotic syndrome. Lancet, 2, 1088-1089.

Sellinger, O. Z., Beaufay, H., Jacques, P., Doyen, A., and de Duve, C. (1960). Tissue fractionation studies. 15. Intracellular distribution and properties of $\beta-\mathrm{N}$-acetylglucosaminidase and $\beta$ galactosidase in rat liver. Biochem. J., 74, 450-456.

Seno, N., Akiyama, F., and Anno, K. (1972). A novel dermatan polysulfate from hagfish skin, containing trisulfated disaccharide residues. Biochim, biophys. Acta (Amst.), 264, 229-233.

Sjöberg, I., Fransson, L. Å., Matalon, R., and Dorfman, A. (1973). Hunter's syndrome: a deficiency of L-idurono-sulfate sulfatase. Biochem. biophys. Res. Commun., 54, 1125-1132.

Sly, W. S., Quinton, B. A., McAlister, W. H., and Rimoin, D. L.
(1973). Beta-glucuronidase deficiency: report of clinical, radiologic, and biochemical features of a new mucopolysaccharidosis. J.Pediat., 82, 249-257.

Spranger, J. W. (1972a). The systemic mucopolysaccharidoses. Ergebn. inn. Med. Kinderheilk., 32, 166-265.

Spranger, J. W. (1972b). Communication at the symposium on mucopolysaccharidoses. Luxemburg.

Spranger, J. W., Koch, F., McKusick, V. A., Natzschka, J., Wiedemann, H. R., and Zellweger, H. (1970). Mucopolysaccharidosis VI (Maroteaux-Lamy's disease). Helv. paediat. Acta, 25, 337362.

Spranger, J. W., Schuster, W., and Freitag, F. (1971). Chondroitin-4sulfate mucopolysaccharidosis. Helv. paediat. Acta, 26, 387-396.

Spranger, J. W., and Wiedemann, H. R. (1969). Lipomucopolysaccharidosis, a second look. Lancet, 2, 270-271.

Spranger, J. W., and Wiedemann, H. R. (1970a). The genetic mucolipidoses. Neuropädiat., 2, 3-16.

Spranger, J. W., and Wiedemann, H. R. (1970b). The genetic mucolipidoses: diagnosis and differential diagnosis. Humangenetik, 9, 113-139.

Spranger, J., Wiedemann, H. R., Tolksdorf, M., Graucob, E., and Caesar, R. (1968). Lipomucopolysaccharidose. Eine neue Speicherkrankheit. $Z$. Kinderheilk., 103, 285-306.

Suzuki, K. (1967). Ganglioside patterns of normal and pathological brains. In Inborn Disorders of Sphingolipid Metabolism, edited by S. M. Aronson and B. W. Volk, pp. 215-230. Pergamon Press, Oxford.

Suzuki, K. (1968). Cerebral $\mathrm{G}_{\mathrm{M}_{1}}$-gangliosidosis: chemical pathology of visceral organs. Science, 159, 1471-1472.

Suzuki, K., and Chen, G. C. (1967). Brain ceramide hexosides in Tay-Sachs disease and generalized gangliosidosis $\left(\mathrm{GM}_{\mathbf{M}_{1}}\right.$. gangliosidosis). J. Lipid Res., 8, 105-113.

Suzuki, K., Suzuki, K., and Chen, G. C. (1968a). Morphological, histochemical and biochemical studies on a case of systemic late infantile lipidosis (generalized gangliosidosis). J. Neuropath. exp. Neurol., 27, 15-38.

Suzuki, K., Suzuki, K., and Chen, G. C. (1968b). GM $\mathrm{M}_{1}$-gangliosidosis (generalized gangliosidosis): morphology and chemical pathology. Path. Europaea, 3, 389-408.

Suzuki, K., Suzuki, K., and Kamoshita, S. (1969). Chemical pathology of $\mathrm{GM}_{1}$-gangliosidosis (generalized gangliosidosis). J. Neuropathol. exp. Neurol., 28, 25-73.

Suzuki, Y., Crocker, A. C., and Suzuki, K. (1971). GM $\mathbf{M}_{1}$-gangliosidosis. Arch. Neurol., 24, 58-64.

Taber, P., Gyepes, M. T., Philippart, M., and Ling, S. (1973). Roentgenographic manifestations of Leroy's I-cell disease. Amer. J. Roentgenol., 118, 213-221.

Taketomi, T., and Yamakawa, T. (1967). Glycolipids of the brain in gargoylism. Japan J. exp. Med., 37, 11-21.

Thieffry, S., Lyon, G., and Maroteaux, P. (1967). Encéphalopathie métabolique associant une mucopolysaccharidose et une sulfatidose. Arch. franç. Pédiat., 24, 425-432.

Thompson, G. R., Nelson, N. A., Castor, C. W., and Grobelny, S. L. (1971). A mucopolysaccharidosis with increased urinary excretion of chondroitin-4-sulfate. Ann. intern. Med., 75, 421-426.

Tondeur, M. (1973). Etude ultrastructurale des mucopolysaccharidoses et d'affections apparentées. Thesis. Université Libre, Brussels.

Tondeur, M., and Loeb, H. (1969). Etude ultrastructurelle du foie dans la maladie de Morquio. Pediat. Res., 3, 19-26.

Tondeur, M., Vamos-Hurwitz, E., Mockel-Pohl, S., Dereume, J. P. Cremer, N., and Loeb, H. (1971). Clinical, biochemical and ultrastructural studies in a case of chondrodystrophy presenting the I-cell phenotype in tissue culture. J. Pediat., 79, 366-378.

Tulkens, P., Trouet, A., and Van Hoof, F. (1970). Immunological inhibition of lysosome function. Nature (Lond.), 228, 1282-1285.

Tuthill, C. R. (1934). Juvenile amaurotic idiocy: marked adventitial growth associated with skeletal malformations and tuberculomas. Arch. Neurol. Psychiat., 32, 198-209.

Vaes, G. (1968). On the mechanisms of bone resorption. The action of parathyroid hormone on the excretion and synthesis of lysosomal enzymes and on the extracellular release of acid by bone cells. J. Cell Biol., 39, 676-697.

Vaes, G. (1973). Digestive capacity of lysosomes. In Lysosomes and Storage Diseases, edited by H. G. Hers and F. Van Hoof, pp. 43-77. Academic Press, New York.

Van Hoof, F. (1970). Acid hydrolases in mucopolysaccharidoses. In Metabolic Regulation and Enzyme Action: FEBS Symposium, edited by A. Sols and S. Grisolia, 19, pp. 339-346. Academic Press, London and New York. 
Van Hoof, F. (1972). Les mucopolysaccharidoses en tant que thésaurismoses lysosomiales. Thesis. Vander, Louvain, 285 pp.

Van Hoof, F. (1973a). Mucopolysaccharidoses. In Lysosomes and Storage Diseases, edited by H. G. Hers and F. Van Hoof, pp. 217-259. Academic Press, New York.

Van Hoof, F. (1973b). $\mathrm{GM}_{1}-$ Gangliosidosis. In Lysosomes and Storage Diseases, edited by H. G. Hers and F. Van Hoof, pp. 305-321. Academic Press, New York.

Van Hoof, F. (1973c). Fucosidosis. In Lysosomes and Storage Diseases, edited by H. G. Hers and F. Van Hoof, pp. 277-290. Academic Press, New York.

Van Hoof, F., and Hers, H. G. (1964). L'ultrastructure des cellules hépatiques dans la maladie de Hurler (gargoylisme). $C . R$. Acad. Sci. (Paris), 259, 1281-1283.

Van Hoof, F., and Hers, H. G. (1967a). Lysosomal enzymes in gargoylism (Abstr.). In Proceedings of the IV Meeting of the Federation of European Biochemical Societies, Oslo, p. 49.

Van Hoof, F., and Hers, H. G. (1967b). L'ultrastructure du foie dans certaines thésaurismoses. Rev. int. Hépat., 17, 815-826.

Van Hoof, F., and Hers, H. G. (1968a). The abnormalities of lysosomal enzymes in mucopolysaccharidoses. Europ. J. Biochem., 7, 34-44.

Van Hoof, F., and Hers, H. G. (1968b). Mucopolysaccharidosis by absence of a-fucosidase. Lancet, 1, 1198.

Van Hoof, F., and Hers, H. G. (1972). The mucopolysaccharidoses as lysosomal diseases. In Sphingolipids, Sphingolipidoses, and Allied Disorders (Advances in Experimental Medicine and Biology, vol. 19), edited by B. W. Volk and S. M. Aronson, pp. 211-223. Plenum Press, New York.

Varadi, D. P., Cifonelli, J. A., and Dorfman, A. (1967). The acid mucopolysaccharides in normal urine. Biochim. biophys. Acta (Amst.), 141, 103-117.

Viala, R., and Gianetto, R. (1955). The binding of sulphatase by ratliver particles as compared to that of acid phosphatase. Canad. J. Biochem., 33, 839-844.

Voelz, C., Tolksdorf, M. Freitag, F., and Spranger, J. (1971). Fucosidose. Mschr. Kinderheilk., 119, 352-355.

von Figura, K., and Kresse, H. (1972). The Sanfilippo B corrective factor: a N-acetyl-a-D-glucosaminidase. Biochem. biophys. Res. Commun., 48, 262-269.

von Hirsch, T., and Peiffer, J. (1955). Uber histologischen Methoden in der Differentialdiagnose von Leukodystrophiën und Lipidosen. Arch. Psychiat. Nervenkr., 194, 88-104.

Walbaum, R., Dehaene, P., Scharfman, W., Farriaux, J. P., Tondeur, M., Vamos-Hurwitz, E., Kint, J. A., and Van Hoof, F. (1973). La mucolipidose de type II (I-cell disease). Arch. franc. Pédiat., $30,577-593$.

Wallace, B. J., Volk, B. W., Schneck, L., and Kaplan, H. (1966). Fine structural localization of two hydrolytic enzymes in the cerebellum of children with lipidoses. J. Neuropath. exp. Neurol., 25, 76-96.

Wattiaux, R. (1966). Etude expérimentale de la surcharge des lysosomes. Thesis. Duculot, Gembloux.

Weissmann, B., and Hinrichsen, D. F. (1969). Mammalian a-acetylgalactosaminidase. Occurrence, partial purification and action on linkages in submaxillary mucins. Biochemistry, 8, 2034-2043.

Weissmann, B., Rowin, G. Marshall, J., and Friederici, D. (1967). Mammalian $a$-acetylglucosaminidase. Enzymic properties, tissue distribution and intracellular localization. Biochemistry, 6, 207-214.

Weissmann, B., and Santiago, R. (1972). a-L-Iduronidase in lysosomal extracts. Biochem. biophys. Res. Commun., 46, 1430-1433.

Wherrett, J. R. (1968). Analysis of glycolipids in the Hurler syndrome. Path. Europaea, 3, 431-439.

Wiedemann, H. R., and Spranger, J. (1968). Lipomucopolysaccharidosis? Lancet, 1, 861-862.

Wiesmann, U. N., and Neufeld, E. F. (1970). Scheie and Hurler syndromes: apparent identity of the biochemical defect. Science, 169, 72-74

Wiesmann, U. N., Lightbody, J., Vassella, F., and Herschkowitz, N. N. (1971a). Multiple lysosomal enzyme deficiency due to enzyme leakage? New Engl. J. Med., 284, 109-110.

Wiesmann, U. N., Vassella, F., and Herschkowitz, N. N. (1971b). 'I-cell' disease: leakage of lysosomal enzymes into extracellular fluids. New Engl. J. Med., 285, 1090-1091.

Winchester, P., Grossman, H., Lim, W. N., and Danes, B. S. (1969). A new acid mucopolysaccharidosis with skeletal deformities simulating rheumatoid arthritis. Amer. J. Roentgenol., 106, 121-128.

Wolfe, H. J., Blennerhasset, J. B., Young, G. F., and Cohen, R. B. (1964). Hurler's syndrome Amer. J. Path. 45, 1007-1027.

Zielke, K., Veath, M. L., and O'Brien, J. S. (1972). Fucosidosis : deficiency of $a$-L-fucosidase in cultured skin fibroblasts. $J$. exp. Med., 136, 197-199. 